\title{
The Regional Climate Impact of a Realistic Future Deforestation Scenario in the Congo Basin
}

\author{
Tom AKkermans, Wim Thiery, And Nicole P. M. VAn LipZig \\ Department of Earth and Environmental Sciences, Katholieke Universiteit Leuven, Heverlee, Belgium
}

(Manuscript received 21 June 2013, in final form 6 December 2013)

\begin{abstract}
The demand for agricultural land in the Congo basin is expected to yield substantial deforestation over the coming decades. Although several studies exist on the climatological impact of deforestation in the Congo basin, deforestation scenarios that are implemented in climate models are generally crude. This study aims to refine current impact assessments by removing the primary forest according to an existing spatially explicit scenario, and replacing it by successional vegetation typically observed for the Congo basin. This is done within the Consortium for Small-Scale Modeling (COSMO) model in climate mode (COSMO-CLM), a regional climate model at $25-\mathrm{km}$ grid spacing coupled to a state-of-the-art soil-vegetation-atmosphere transfer scheme (Community Land Model). An evaluation of the model shows good performance compared to in situ and satellite observations. Model integrations indicate that the deforestation, expected for the middle of the twenty-first century, induces a warming of about $0.7^{\circ} \mathrm{C}$. This is about half the greenhouse gas-induced surface warming in this region, given an intermediate emission scenario (A1B) with COSMO-CLM driven by the ECHAM5 global climate model. This shows the necessity of taking into account deforestation to obtain realistic future climate projections. The deforestation-induced warming can be attributed to reduced evaporation, but this effect is mitigated by increased albedo and increased sensible heat loss to the atmosphere. Precipitation is also affected: as a consequence of surface warming resulting from deforestation, a regional heat low develops over the rain forest region. Resulting low-level convergence causes a redistribution of moisture in the boundary layer and a stabilization of the atmospheric column, thereby reducing convection intensity and hence precipitation by $5 \%-10 \%$ in the region of the heat low.
\end{abstract}

\section{Introduction}

Biogeophysical interactions between land and atmosphere (i.e., fluxes of energy, moisture, and momentum) are directly affected by the characteristics of the land surface (e.g., albedo). Modifying these can significantly alter the surface energy and water balance in a particular region, and hence its climate (Bonan 2008). The Congo basin hosts the second-largest contiguous block of humid tropical forest in the world after the Amazon, consisting of over $1.80 \times 10^{8}$ ha $\left(1 \mathrm{ha}=1.0 \times 10^{4} \mathrm{~m}^{2}\right)$ of vast primary forest (Mayaux and Malingreau 2001). The principal driver of deforestation in this region is forest clearing for agriculture (Norris et al. 2010), mainly in the form of shifting cultivation (Russell et al. 2011). Because of increasing human population growth rates,

Corresponding author address: Tom Akkermans, KU Leuven, Department of Earth and Environmental Sciences, Celestijnenlaan 200E, 3001 Heverlee (Leuven), Belgium.

E-mail: tom.akkermans@ees.kuleuven.be the demand for agricultural land in the Congo basin may increase by $100 \%$ the next 20 years (Zhang et al. 2006), which is a reason for concern since the farmers lack any incentive for production intensification (Wilkie et al. 2000). Studies of anthropogenic biogeophysical climate change are necessary to raise awareness about potential consequences of unsustainable development (such as shifting cultivation with high population pressure) and facilitate science-based policy measures in order to protect people's livelihood for the next generations. Therefore, it is important to have a realistic quantification of the deforestation impact on the future climate in the Congo basin.

Biogeophysically induced climate change is often studied using a numerical modeling approach. A classic approach to quantify the climatological effects of deforestation is through the implementation of idealized scenarios, in which usually all forest is removed and replaced by a single land cover type such as bare soil or grass. Early global climate model (GCM) studies on tropical deforestation solely concentrated on Amazon deforestation (e.g., Henderson-Sellers and Gornitz 1984; 
Lean and Warrilow 1989; Shukla et al. 1990). The first to include deforestation in the Congo basin were Polcher and Laval (1994), followed by many others (McGuffie et al. 1995; Sud et al. 1996; Zhang et al. 1996; VarejãoSilva et al. 1998; Semazzi and Song 2001; Claussen et al. 2001; Zhang et al. 2001; Osborne et al. 2004; Snyder et al. 2004; Findell et al. 2006). All studies point to a regional surface warming as a consequence of tropical deforestation, and most of them point to a decrease in precipitation. More recently, regional climate model (RCM) studies (e.g., Nogherotto et al. 2013) were performed at higher horizontal resolution $\left(0.50^{\circ}\right)$, allowing for an improved understanding of the atmospheric response to total forest removal.

Although useful as "thought experiments" from which a lot has been learned, the abovementioned studies cannot be considered as realistic projections, since they are all based on the unrealistic assumption of total forest removal with furthermore a completely homogeneous conversion to, for example, pasture (O'Brien 2000; Pielke et al. 2007). The following improvements are necessary in order to make the projections more realistic. 1) A first step is to improve the deforestation scenario: instead of simply removing all the forest or using chessboard-type deforestation patterns, spatially explicit scenarios should be used, which are often based on algorithms using socioeconomic input data and assumptions for the future. 2) A necessary condition for such spatially explicit scenarios is an improvement of the horizontal model grid resolution. 3) Furthermore, apart from the spatial patterns of future deforestation, the absolute amount of future forest removal should be within the range of plausible estimates instead of earlier-used rough assumptions such as a complete basinwide conversion of forest to, for example, pasture or crops. 4) Given the crucial importance of the interplay between vegetation and the overlying atmosphere, and acknowledging the great progress that the scientific community has made in recent years to develop comprehensive land surface models, the use of a state-of-the-art soil-vegetation-atmosphere transfer (SVAT) scheme within the climate model is absolutely mandatory for deforestation impact studies. 5) However, such an increase in complexity is only beneficial when detailed information about replacement vegetation is available, that is, what vegetation type(s) will substitute the removed forest.

Some of these improvements are already incorporated in existing studies, such as that of Maynard and Royer (2004), who complemented their GCM with the spatially explicit Integrated Model to Assess the Global Environment (IMAGE) 2.2 land use scenario (Strengers et al. 2004), used in, for example, the emission scenarios of the Intergovernmental Panel on Climate Change (IPCC) (improvement 1). The horizontal grid resolution was improved accordingly to $0.90^{\circ}$ (improvement 2), and more recent RCM studies improved further on this to a resolution of $0.50^{\circ}$ (Paeth et al. 2009; Nogherotto et al. 2013). Paeth and Thamm (2007) and Paeth et al. (2009) generated future deforestation scenarios using a stochastic algorithm, constrained by deforestation estimates from the Food and Agricultural Organization (FAO) and demographic assumptions from the United Nations (improvement 3).

The goal of this study is to quantify and understand regional climate impact of future deforestation in the Congo basin, taking into account all above-mentioned improvements in order to achieve more realism. A highresolution spatially explicit scenario of future forest removal for this particular region is used (Justice et al. 2001) (improvement 1). Model integrations are performed on a-for this type of research unprecedented-small scale of $0.22^{\circ}(\sim 25 \mathrm{~km}$; improvement 2$)$. Contrary to assumptions such as a complete replacement of forest by, for instance, pasture, the total amount of forest loss in this study is situated within the range of plausible estimates for deforestation in the next few decades (improvement 3). A state-of-the-art SVAT scheme Community Land Model is used, including all above-mentioned detailed SVAT features (improvement 4). Finally, the removed portion of primary forest is replaced by a combination of fallow vegetation types typical of the Congo basin (improvement 5), based on remote sensing data and supported by field observations (Akkermans et al. 2013).

This paper is structured as follows. Section 2 introduces the theoretical background on the response of surface energy balance, temperature, and precipitation on tropical deforestation. In section 3 , the climate model, the validation data and procedures, and the deforestation scenario are documented. The present-day climate is shown and extensively validated in section $4 a$, while section $4 \mathrm{~b}$ presents the impacts of deforestation and increased greenhouse gas (GHG) concentrations on the surface climate, and explains the underlying mechanisms for this response. Section $4 \mathrm{c}$ decomposes the temperature signal into different direct (biogeophysical) and indirect (feedback) contributions of the energy balance components. Section 5 situates the results obtained in this study in existing literature and discusses some important implications for the ecosystem. Finally, section 6 includes a summary and the concluding remarks.

\section{Theory}

The biogeophysical impact of tropical deforestation can theoretically be understood by investigating the surface energy balance: 


$$
\epsilon \sigma T_{s}^{4}=\mathrm{SW}_{i}-\mathrm{SW}_{o}+\mathrm{LW}_{i}-\mathrm{LE}-H-G,
$$

where $\epsilon$ is surface emissivity, $\sigma$ is the Stefan-Boltzmann constant, $\mathrm{SW}_{i}$ is incoming shortwave radiation, $\mathrm{SW}_{o}$ is outgoing shortwave (SW) radiation, $\mathrm{LW}_{i}$ is incoming longwave (LW) radiation, LE is latent heat flux, $H$ is sensible heat flux, and $G$ is ground heat flux.

As described in several numerical impact studies (Shukla et al. 1990; Dirmeyer and Shukla 1994; Zeng and Neelin 1999; Zhang et al. 2001; Snyder et al. 2004; Salih et al. 2013), the change in surface temperature resulting from tropical deforestation $\left(\delta T_{s}\right)$ is to a first order caused by a decrease in LE because of lower evaporation and transpiration. This is only partly compensated by an increase in reflected or outgoing solar radiation resulting from the higher albedo of replacement vegetation. The resulting energy excess at the surface is consumed essentially in two ways: first, to raise the radiative temperature of the surface with a corresponding increase in outgoing LW radiation, and second, to create a stronger upward sensible heat flux caused by the increasing temperature gradient between surface and atmosphere. This partially buffers the temperature increase at the surface (acting as a negative feedback) and heats the atmosphere aloft. In this way the increase in temperature is distributed over surface and atmosphere, and the energy budget is kept in balance in the long term. Other feedbacks exist through the modification of cloud cover, which influences incoming solar and thermal radiation ( $\mathrm{SW}_{i}$ and $\mathrm{LW}_{i}$, respectively).

Concerning the impact of deforestation on regional precipitation, less scientific consensus exists about the decisive processes that play a role in defining sign and magnitude of the impact (Polcher 1995; Pielke et al. 2007). Most of the modeling studies predict significant decreases in regional precipitation; however, some expect the opposite. These differences have several reasons: first, the sensitivity of the model to deforestation partly depends on the parameters describing the surface characteristics (Voldoire and Royer 2004). Second, models use different parameterizations for convection, clouds, and the interaction between radiation and clouds (Polcher 1995). Finally, and potentially depending on previous reasoning, differences exist in the sign and magnitude of change in moisture convergence and its relative importance compared to counteracting factors (such as decreasing moisture flux from vegetation to atmosphere). This is shown by Dirmeyer and Shukla (1994), who demonstrated the indirect and nonlinear dependence of precipitation change on albedo change, through the modulation of regional moisture convergence. The observed response of precipitation to tropical deforestation is also very diverse with a wide range of results and conclusions (Warren 1974; Fleming 1986; Meher-Homji 1991; Chu et al. 1994; Chen et al. 2001; Durieux et al. 2003). Hence, especially for investigating the impact of deforestation on precipitation, it is important to include all possibly relevant biogeophysical interactions and atmospheric processes in the climate model. This can only be achieved by using a finescale regional climate model with a state-of-the-art SVAT scheme.

\section{Model, methodology, and data}

\section{a. Model choice and descriptions}

In this study, we use the regional-scale nonhydrostatic Consortium for Small-Scale Modeling (COSMO) model in climate mode (COSMO-CLM; Rockel et al. 2008), version 4.0, which has been evaluated by Jaeger et al. (2008). The default SVAT scheme of COSMO-CLM is the multilayer land surface model known as TERRA-ML (Grasselt et al. 2008), although in this study the climate model is instead coupled to the more advanced Community Land Model, version 3.5 (Oleson et al. 2004, 2008). This coupled model is referred to as COSMO$\mathrm{CLM}^{2}$ and is described by Davin et al. (2011), who demonstrated its advantage compared to the standard model. The Community Land Model is developed and maintained by the National Center for Atmospheric Research (NCAR) and has been extensively evaluated by Oleson et al. (2008) and Stöckli et al. (2008). Akkermans et al. (2012) compared the performance of TERRA-ML and Community Land Model independent from their atmospheric host models for four African flux sites, and found that the Community Land Model better fits the observed turbulent fluxes. For instance, the deep roots of evergreen tropical tree vegetation in Community Land Model allowed a continuous and high evapotranspiration (ET) throughout the year, as observed, while TERRA-ML underestimated ET during the drier periods. Also other parameterizations, such as the calculation of the surface albedo and lake temperatures, are more sophisticated in Community Land Model (e.g., Thiery et al. 2014a,b), resulting in a better simulation of the energy balance and turbulent fluxes.

RCMs dynamically downscale the global driving lateral boundary conditions with a coarse resolution to a regional finescale model grid. Two types of boundary conditions are used in this study: first the state-of-the-art European Centre for Medium-Range Weather Forecasts (ECMWF) Interim Re-Analysis (ERA-Interim; Dee et al. 2011), which is available for 1989-2012 on a horizontal resolution of $0.7^{\circ}$. The second type of boundary conditions are simulations from a GCM: in an intercomparison study of Van Ulden and Van Oldenborgh 
(2006) evaluating 23 GCMs, ECHAM5 (Roeckner et al. 2003; Jungclaus et al. 2006) shows the best performance with both highest spatial correlation and explained spatial variance for pressure fields compared to the 40-yr ECMWF Re-Analysis (ERA-40), globally as well as in the tropics. Tanaka et al. (2005) compared intensities of large-scale tropical atmospheric circulations (Hadley, Walker, and monsoon), showing that ECHAM5 has the best correspondence with National Centers for Environmental Prediction (NCEP)-NCAR reanalysis. Consequently, this GCM has been chosen for this study. Archived model simulations are available for the periods 1900-2000 (Roeckner et al. 2006a) and 2000-2100 (Roeckner et al. 2006b) and are integrated using observed and future projected GHG forcing, respectively. Because no "best guess" forcing scenario exists among the Special Report on Emissions Scenarios (SRES) storylines (Nakicenovic et al. 2000), and since it is outside the scope of this study to investigate the GCM's sensitivity to different emission scenarios, the "medium forcing" scenario has been chosen (A1B) with intermediate warming projections for Africa compared to the low ("mitigation"; B1) and high ("fossil fuel intensive"; A2) extremes (Christensen et al. 2007; Müller 2009). ECHAM5 has the second highest transient climate response and the fifth highest equilibrium climate sensitivity among 19 GCMs participating in the IPCC's Fourth Assessment Report (AR4; Randall et al. 2007). These are indices for the overall model sensitivity to a given greenhouse gas forcing and are not related to model performance, reliability, or accuracy. The horizontal GCM grid resolution is $1.87^{\circ}$

\section{b. Model simulations and setup}

The COSMO-CLM ${ }^{2}$ model is used to generate four climate simulations. First, the present-day climate (19902009 ) is simulated using reanalysis as boundary conditions: this simulation is referred to as PRR (for present-day reanalysis-driven reference simulation). The simulation is repeated, only changing the driving boundary conditions to ECHAM5: this simulation is referred to as PGR (for present-day GCM-driven reference simulation). An additional simulation for 2041-60, called FGR (for future GCM-driven reference simulation), is performed using ECHAM5. Finally, a fourth simulation similar to FGR is done, but now with a deforestation scenario imposed on the land surface scheme: this simulation is referred to as FGD (for future GCM-driven deforestation simulation).

Each model simulation is conducted for a period of $21 \mathrm{yr}$, from which the first year is considered as spinup time and ignored in the analyses (1989 for present day and 2040 for future). Analysis of soil temperatures and

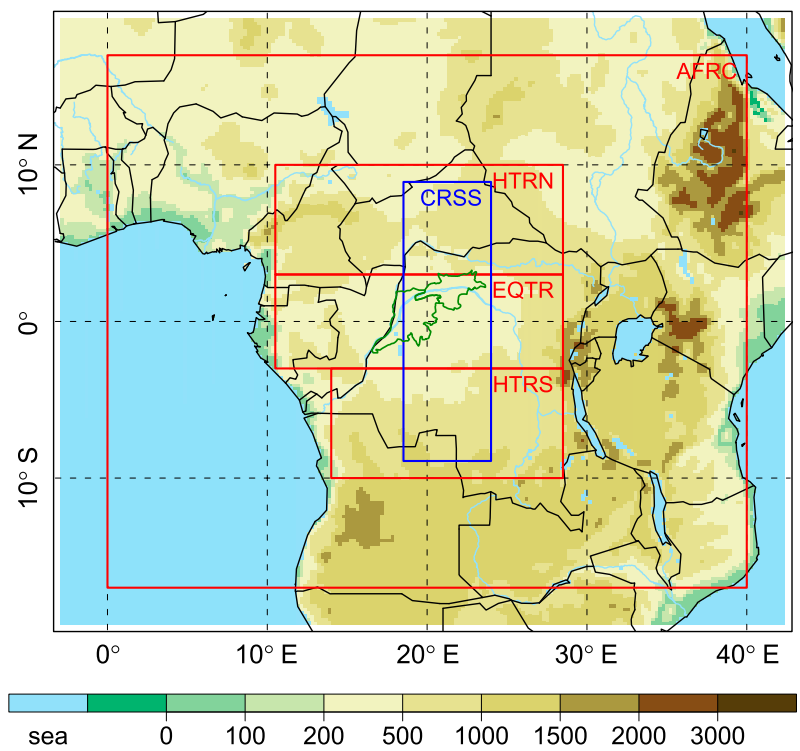

FIG. 1. Model domain $\left(19.69^{\circ} \mathrm{S}-19.69^{\circ} \mathrm{N}, 3.26^{\circ} \mathrm{W}-42.72^{\circ} \mathrm{E}\right.$; center at $0^{\circ}, 19.73^{\circ} \mathrm{W}$ ) used in this study with corresponding topography and regions of interest: tropical Africa (AFRC; $17^{\circ} \mathrm{S}-17^{\circ} \mathrm{N}, 0^{\circ}-$ $40^{\circ} \mathrm{E}$ ), equatorial tropics (EQTR; $3.0^{\circ} \mathrm{S}-3.0^{\circ} \mathrm{N}, 10.5^{\circ}-28.5^{\circ} \mathrm{E}$ ), northern humid tropics (HTRN; $\left.3.0^{\circ}-10.0^{\circ} \mathrm{N}, 10.5^{\circ}-28.5^{\circ} \mathrm{E}\right)$, and southern humid tropics (HTRS; $10.0^{\circ}-3.0^{\circ} \mathrm{S}, 14.0^{\circ}-28.5^{\circ} \mathrm{E}$ ). CRSS $\left(19^{\circ} \mathrm{S}-19^{\circ} \mathrm{N}, 18.5^{\circ}-24^{\circ} \mathrm{E}\right)$ is a special region of interest for which zonally averaged atmospheric cross sections are made. In dark green, two administrative districts of DR Congo are indicated, namely Mongala (north) and Equateur (south).

the water table depth indicate that $1 \mathrm{yr}$ of spinup time is sufficient: domain-averaged water table depth and soil bottom temperature evolve to normal climatological values within the first year. Domain-averaged monthlymean ground temperatures all lay within 2 standard deviations from the multiannual monthly-mean values, except for the first six months of 1989.

The model has a horizontal grid of $210 \times 180$ points with a spatial resolution of $0.22^{\circ}(\sim 25 \mathrm{~km})$ (Fig. 1) and a time step of $120 \mathrm{~s}$ (similar to Panitz et al. 2012). GHG concentrations are prescribed following the transient A1B scenario, whereas aerosol concentrations follow the climatology proposed by Tanré et al. (1984). Given the different meteorological conditions in the tropics compared to the midlatitudes, the default configuration of the model was modified analogous to the Coordinated Regional Climate Downscaling Experiment in Africa (CORDEX-Africa) setup (Panitz et al. 2012), with a raised top of the atmosphere $(30 \mathrm{~km})$ and increased number of levels in the vertical (35). The Congo basin rain forest is centered in the model domain, and in the nondeforested reference simulations (PRR, PGR, and FGR), it is represented by a vast amount of grid cells containing mainly the vegetation type broadleaf evergreen tropical tree (Fig. 2a): for instance, within the subregion of 


\section{Rainforest abundance in COSMO-CLM ${ }^{2}$}
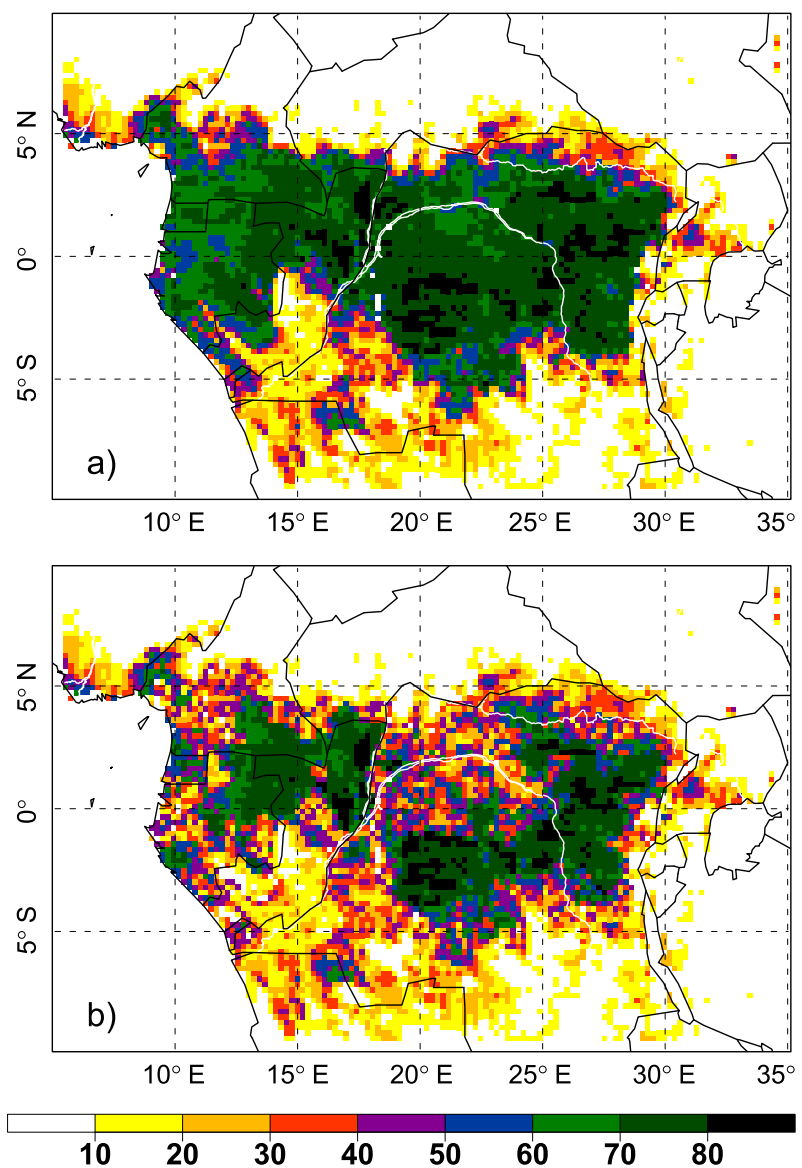

Difference (deforestation scenario)

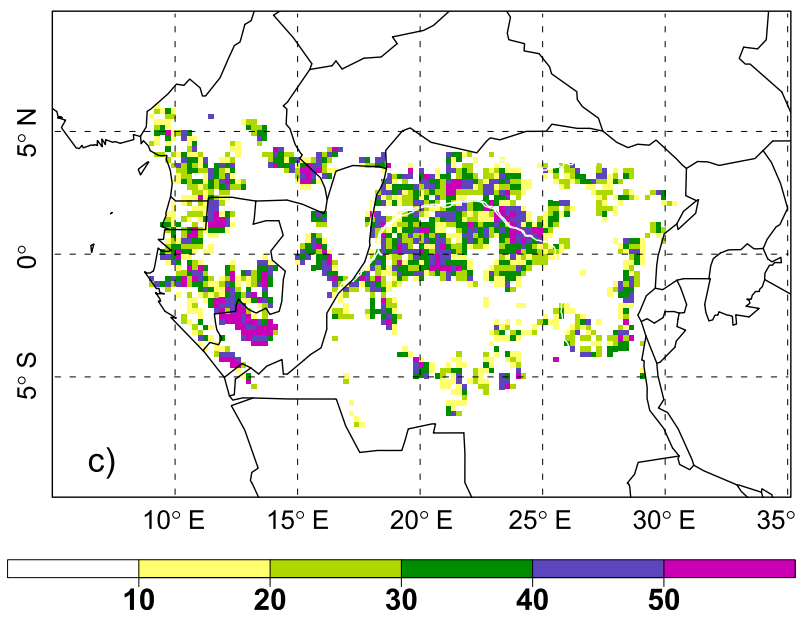

FIG. 2. Areal abundance of rain forest (percent per grid cell) in COSMO-CLM ${ }^{2}$ for (a) the reference simulations and (b) the deforested simulation, according to (c) the scenario from Justice et al. (2001) (percent decrease per grid cell). the equatorial tropics $\left(\mathrm{EQTR} ; 3.0^{\circ} \mathrm{S}-3.0^{\circ} \mathrm{N}, 10.5^{\circ}-28.5^{\circ} \mathrm{E}\right.$; Fig. 1), this vegetation type occurs in each vegetated pixel and covers $69 \%$ of the area in the entire subregion.

\section{c. Data for model evaluation}

Model performance is tested by comparing simulated and observed spatial patterns and mean annual cycles for different climatological variables, listed in Table 1. Observed monthly-mean near-surface temperature is provided by the gridded Climatic Research Unit (CRU) dataset (Harris et al. 2013), constructed by spatiotemporal interpolation of temperature recorded by ground stations. In contrast to satellite-based observations, spatial and temporal coverage of in situ data in central Africa is rather limited. To avoid interpolation-dependent deviations, regional temperature averages of both simulations and observations are calculated using only CRU grid cells containing an actual ground station, and using only the gap-free time span.

No gridded direct observations of land evapotranspiration (or equivalent latent heat flux) exist. Available datasets, however, are indirectly derived (proxy observations), and therefore two essentially different data products have been chosen for intercomparison and validation purposes in this study: GLEAM (Global Land Surface Evaporation: The Amsterdam Model) and FLUXNET-MTE (MTE is for model tree ensembles). These are respectively based on calculations from gridded climatological fields (temperature, precipitation, soil moisture, radiation, etc.) and global upscaling of observations from eddy-covariance flux towers using model tree ensembles.

\section{d. Deforestation scenario}

The projected spatial extent of future deforestation in the Congo basin is taken from Justice et al. (2001) (Fig. 2c). This regional scenario is based on a probability algorithm driven by the determinant factors explaining deforestation, being population growth, road density, logging concessions, and forest fragmentation. It projects a general shrinkage toward the forest interior and a fragmentation into three large forest blocks: two in the Democratic Republic of the Congo (hereafter DR Congo) and one west of the Congo River (Fig. 2b). Since the spatial resolution of the COSMO-CLM ${ }^{2}$ grid and the scenario are different $\left(0.22^{\circ}\right.$ and $0.10^{\circ}$, respectively), the scenario is remapped. The detailed remapping procedure is clarified in appendix A.

Although useful as a projection of the spatial extent of deforestation, the total amount of forest removal in the original scenario is likely a worst-case scenario (see appendix B). In addition, given the binary nature of the scenario, it is assumed that each postclearing deforested 


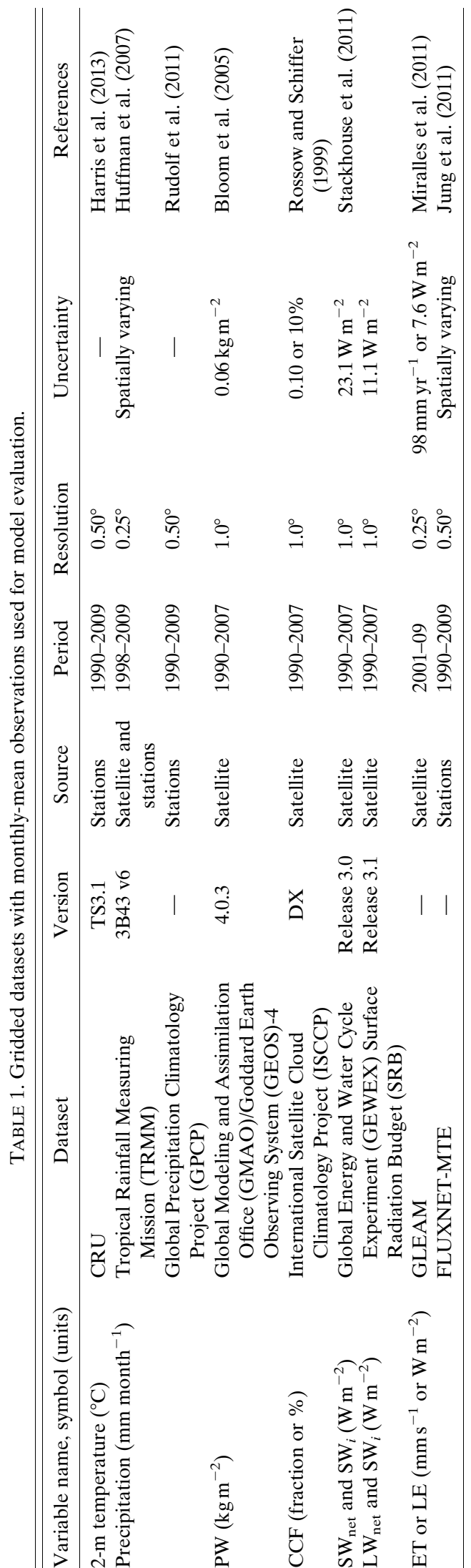

TABLE 2. Recently observed NADR and corresponding projection of total forest removal $r$ by 2050 for tropical Africa; $r$ is calculated using Eq. (B1).

\begin{tabular}{lcc}
\hline \multicolumn{1}{c}{ Source } & NADR (\%) & $r(\%)$ \\
\hline $\begin{array}{l}\text { Original scenario of Justice et al. (2001) } \\
\quad \text { used in this study }\end{array}$ & 0.73 & 30.6 \\
Potapov et al. (2012) & 0.25 & 11.8 \\
Ernst et al. (2010) & 0.27 & 12.6 \\
Achard et al. (2002) & 0.36 & 16.5 \\
Zhang et al. (2005) & 0.42 & 19.0 \\
FAO (2000)* & 0.43 & 19.4 \\
Average & 0.35 & 16.1 \\
\hline
\end{tabular}

* Derived from the pan-tropical remote sensing survey.

grid cell is completely forest-free: this is not realistic since many smaller patches of primary forest remain intact because of, for instance, local topography or soil conditions. Therefore, the scenario has been modified with a scale factor in order to match currently observed deforestation rates in the Congo basin (Table 2). The detailed procedure is described in appendix $\mathrm{B}$. The resulting deforested vegetation map, which is used in COSMO-CLM ${ }^{2}$, is shown in Fig. 2b. The assumptions of the deforestation scenario and its compatibility with the emission scenario are further discussed in section $5 \mathrm{~b}$.

The amount of forest removal within a grid cell (which is variable given the conservative remapping procedure) is replaced by successional fallow vegetation according to the following observed proportions, taken from Akkermans et al. (2013): 5\% bare soil, 22\% crops, 9\% grass, $33 \%$ forest regrowth, and $30 \%$ secondary forest. This replacement land cover is the result of several shifting cultivation cycles with successional fallow stages occurring together, hence called "successional vegetation" hereafter. Some of these vegetation types are not by default included in the Community Land Model, so their parameters have been added to the original model (details of this procedure can be found in appendix C).

\section{Results}

\section{a. Evaluation of the model}

\section{1) NEAR-SURFACE TEMPERATURE AND PRECIPITATION}

The overall spatial patterns of observed near-surface temperature (Fig. 3a) are represented well by both PRR and PGR models, with biases most often staying below $1^{\circ} \mathrm{C}$ (Figs. 3b,c). The warmest regions are present at approximately $15^{\circ} \mathrm{N}$ near Goa (Mali) and Khartoum (Sudan). Over the coldest locations, most notably the high plateau of Angola, the Ethiopian highlands, and the 


\section{Evaluation of simulated temperature}
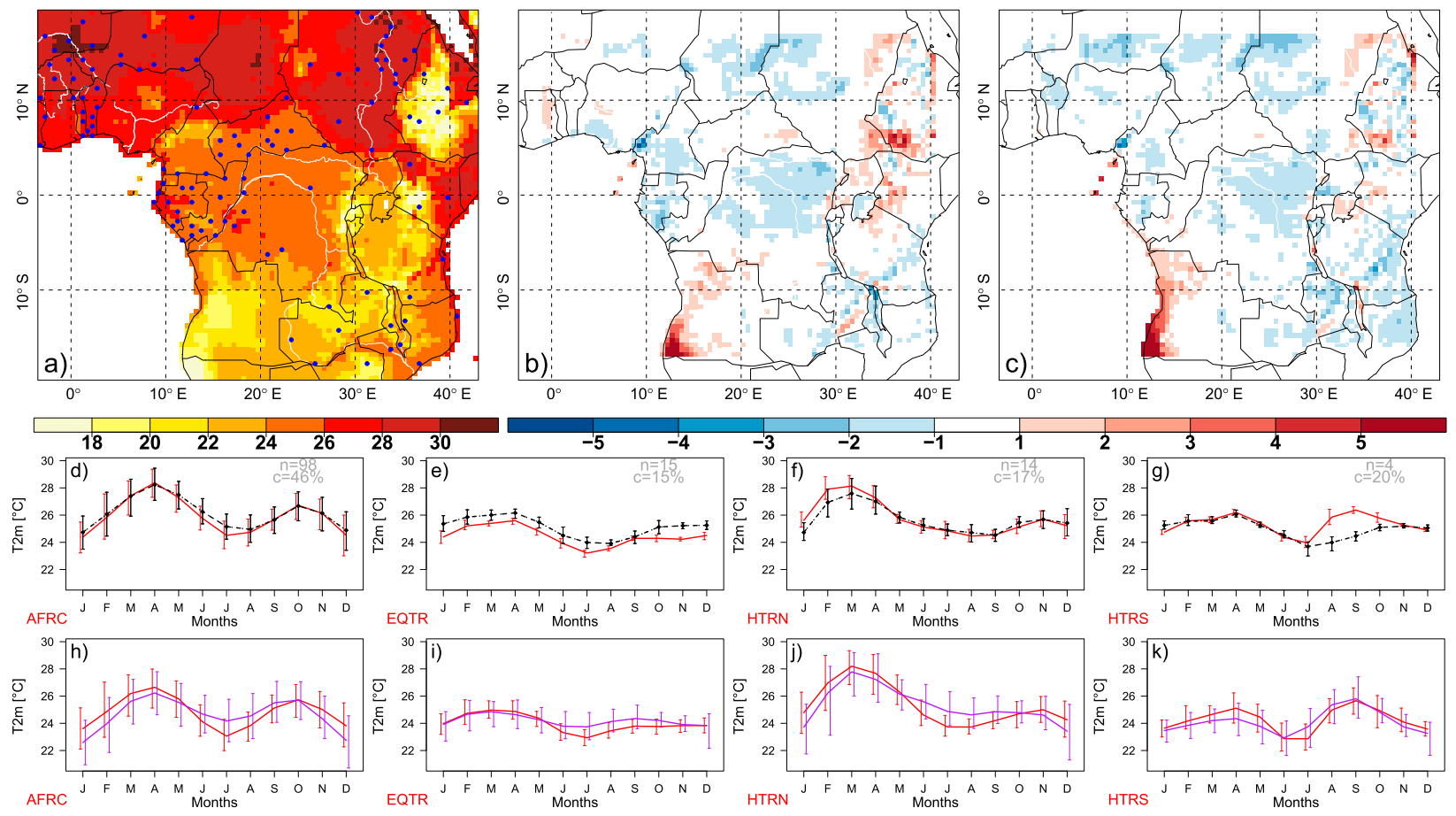

FIG. 3. (a) The 1990-2009 observed mean 2-m temperature $\left({ }^{\circ} \mathrm{C}\right)$ from the gridded CRU dataset (stations indicated by blue dots). Average difference between modeled and CRU observed 2-m temperature over the 1990-2009 period (model minus CRU) for (b) the reanalysis-driven reference simulation $\left(\mathrm{PRR} ; \mathrm{RMSE}=0.30^{\circ} \mathrm{C}\right.$ for AFRC) and (c) the GCM-driven reference simulation $(\mathrm{PGR} ; \mathrm{RMSE}=$ $0.79^{\circ} \mathrm{C}$ for AFRC). Regional mean annual cycle for CRU grid cells containing actual ground station measurements are shown for (d) AFRC, (e) EQTR, (f) HTRN and (g) HTRS (see Fig. 1 for identification of the regions). In gray font, the number of ground stations for each region $n$ and the mean relative gap-free time span $c$ are indicated. Annual cycles are shown for CRU (dashed black line). (h)-(k) Regional mean annual cycle including all grid cells for model output of PRR (red) and model output of PGR (purple). Vertical bars indicate the interannual variability.

mountain ranges associated with the East African Ridge, PRR depicts a warm bias. In the lowland Congo basin (Gabon, Republic of the Congo, DR Congo, and Central African Republic), temperature is uniformly distributed and tempered by monsoon cloud cover (between $24^{\circ}$ and $26^{\circ} \mathrm{C}$ ). This is mostly well represented by PRR, except for the cold bias in northern DR Congo. Delineation with bordering temperature zones is mostly well captured, as demonstrated by the $26^{\circ} \mathrm{C}$ border in the Central African Republic $\left(\sim 8^{\circ} \mathrm{N}\right)$ and the $24^{\circ} \mathrm{C}$ border in southern DR Congo $\left(\sim 8^{\circ} \mathrm{S}\right)$ (not shown).

The annual cycle of temperature is well captured by COSMO-CLM ${ }^{2}$ : for the entire domain, very close correspondence exists between the observations and the present-day reference model (PRR) (Fig. 3d). Observed temperature shows a bimodal annual cycle with maxima during the seasons March-May (MAM) and SeptemberNovember (SON), with modeled temperature almost perfectly matching phase and amplitude of the cycle (deviations $<0.5^{\circ} \mathrm{C}$ ). In the equatorial region, a small quasi-systematic underestimation of less than $1^{\circ} \mathrm{C}$ can be noticed (Fig. 3e). A significant model deviation from the observations (about $2^{\circ} \mathrm{C}$ ) occurs in the southern humid tropics (region HTRS: $3.0^{\circ}-10.0^{\circ} \mathrm{S}, 14.0^{\circ}-28.5^{\circ} \mathrm{E}$ ) during the months August and September (Fig. 3g). However, in this region the uncertainty in the observed regional average is largest as the regional mean annual cycle is based on only four stations.

A comparison of PRR and PGR (Figs. $3 \mathrm{~h}-\mathrm{k}$ ) is based on the full 20-yr climatological mean on all grid cells within the respective regions of interest. Deviations of PGR are because of the different boundary conditions of ECHAM5. The model captures the overall climatology: the difference between minimum and maximum monthly averages in PGR is roughly comparable to the PRR model, indicating a sufficient simulation of interannual variability. The seasonality, or intraannual amplitude, is slightly too weak in PGR because of the ECHAM5 boundary conditions, with a small warm bias during the coldest months [June-August (JJA)] and a small cold bias during the warmest months (MAM). 


\section{Evaluation of simulated precipitation}
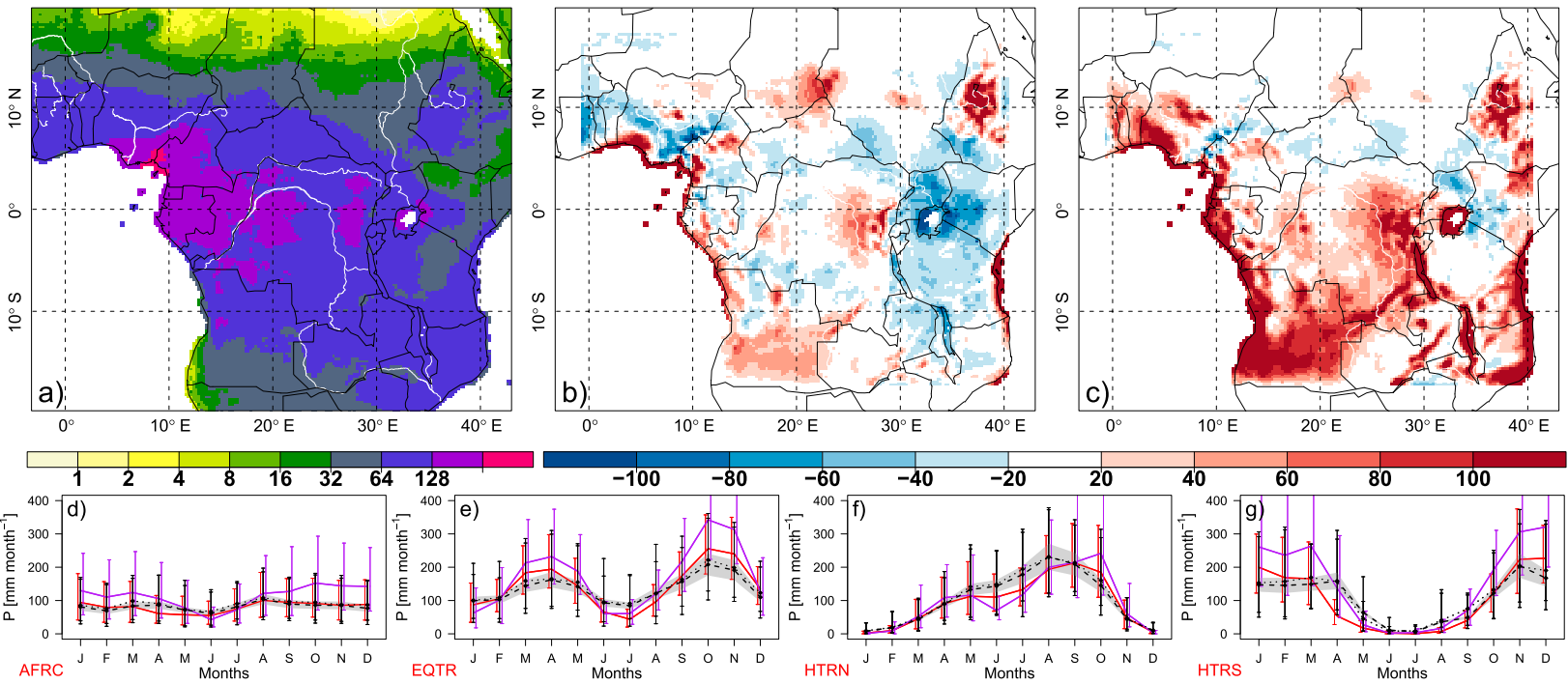

FIG. 4. (a) The 1998-2009 observed precipitation $\left(\mathrm{mm} \mathrm{month}^{-1}\right)$ from the TRMM dataset; Average difference between modeled and TRMM observed precipitation over the 1998-2009 period (model minus TRMM) for (b) the reanalysis-driven reference simulation (PRR; $\mathrm{RMSE}=10.93 \mathrm{~mm}$ month $^{-1}$ for AFRC) and (c) the GCM-driven reference simulation (PGR; RMSE $=41.34 \mathrm{~mm} \mathrm{month}^{-1}$ for AFRC). (d)-(g) As in Figs. 3h-k, but for mean precipitation from TRMM (dashed black line), GPCP (dotted black line), model output of PRR (red), and model output of PGR (purple). Vertical bars indicate the interannual variability. Since the satellite-based TRMM product does not contain any spatiotemporal interpolation, the regional averaged annual cycles of observations, PRR, and PGR are shown together. The gray shading indicates the uncertainty on the observations, as provided by the authors.

Precipitation in the COSMO-CLM ${ }^{2}$ model is simulated with adequate performance, regarding the spatial patterns as well as the amplitude and phase of the annual cycle. Generally, biases are smaller than $40 \mathrm{~mm}$ month $^{-1}$ in PRR (Fig. 4b) and the observed monthly-mean precipitation corresponds closely to PRR (Figs. 4d-g). The coastal wet bias is a common error in RCMs over West Africa and is likely as a result of a too strong convection incitement in off-shore grid boxes induced by the orography in coastal grid boxes (Paeth et al. 2011). An overestimation of PGR during the wet season is clearly present (Figs. $4 \mathrm{~d}-\mathrm{g}$ ), indicating the poorer performance of ECHAM5, which is passed on to COSMO-CLM ${ }^{2}$ via the boundary conditions. A closer look at the ECHAM5 model output reveals higher SSTs (about $2^{\circ}-3^{\circ} \mathrm{C}$ ) and more atmospheric moisture (about $5-10 \mathrm{~kg} \mathrm{~m}^{-2}$ ) over the model domain compared to ERA-Interim (not shown), both being plausible reasons for overestimated convection and monsoon precipitation in central Africa. The warm bias in the surface waters of ECHAM5 is clearly demonstrated by Kothe et al. (2014) and originates from the lack of sufficient stratocumulus clouds, a common feature among state-of-the-art coupled models (Jungclaus et al. 2006). A sensitivity study with varying SSTs by Paeth (2004) demonstrated the influence of tropical SSTs on monsoon precipitation in this region, with positive precipitation differences of up to $500 \mathrm{~mm} \mathrm{month}^{-1}$ associated with an SST rise of $+4^{\circ} \mathrm{C}$.

\section{2) OTHER VARIABLES}

Apart from near-surface temperature and precipitation, the model has also been evaluated for column precipitable water $(\mathrm{PW})$, cloud cover fraction $(\mathrm{CCF})$, and various components of the energy balance (Table 1 ). Very good correspondence exists between observations and model output for PW (Figs. 5a-c) and net LW radiation at the surface (Figs. 6a-c), with only minor deviations between PRR and PGR.

At the top of the atmosphere (TOA), net LW radiation (Figs. 5d-f) is equal to outgoing LW radiation (OLR) and can be regarded as a measure for vertical extent of convective clouds: deeper clouds result in colder cloud-top temperatures and hence a less negative OLR (Kothe et al. 2014). Comparing the two simulations with different boundary conditions, PGR exhibits in general a less negative OLR reflecting deeper clouds compared to PRR, which is in line with the enhanced convection and precipitation in this model integration, because of the ECHAM5 boundary conditions (Figs. 4d-g). A similar but less distinct intermodel deviation can be noticed for the horizontal extent: fractional cloud cover is up to $10 \%$ lower in PRR compared to PGR (Figs. 5g-i). 

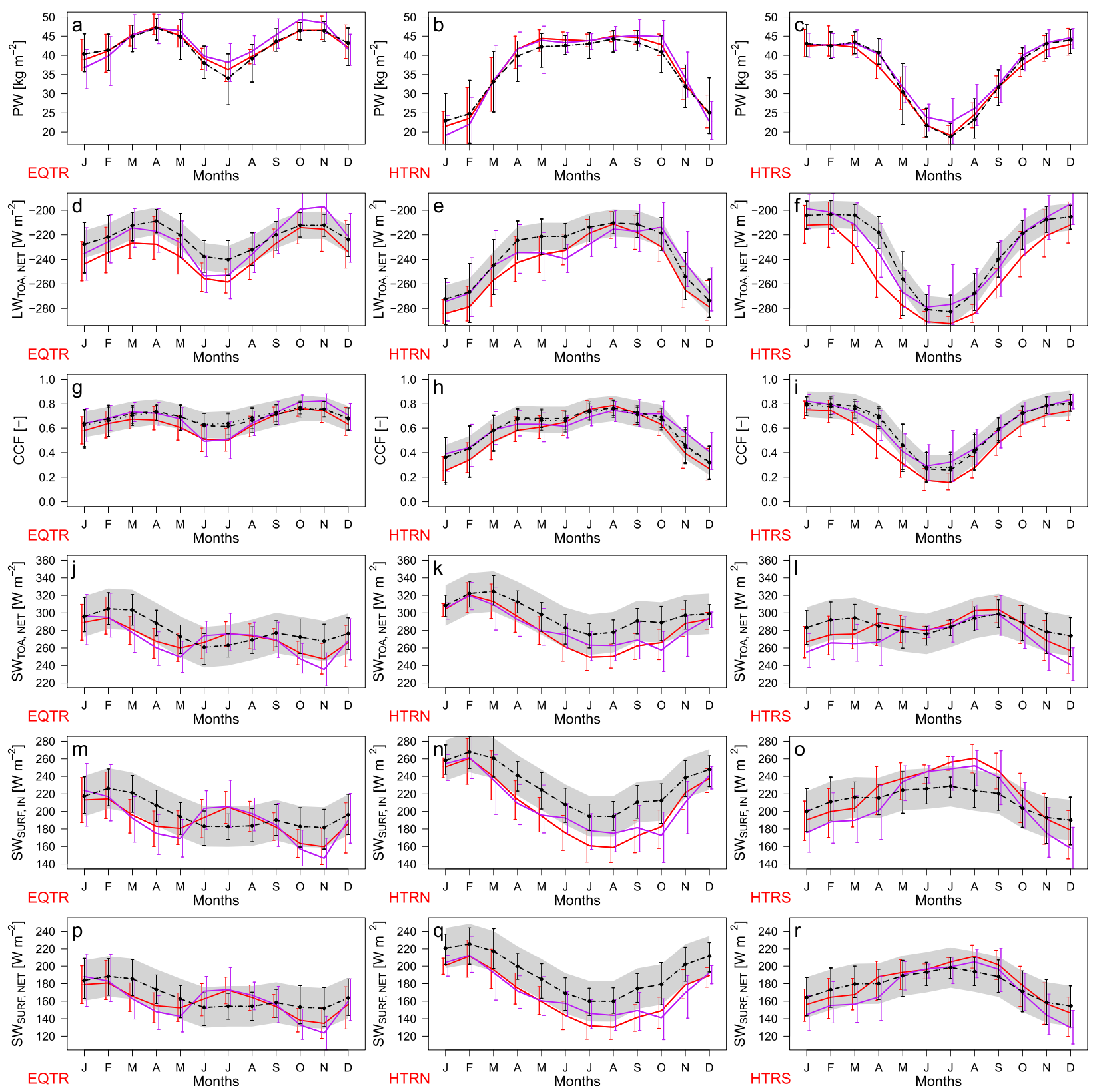

FIG. 5. Mean annual cycles during 1990-2007 for (a)-(c) PW, (d)-(f) $\mathrm{LW}_{\text {net }}$ at TOA (LW $\mathrm{LW}_{\mathrm{TO}, \mathrm{net}}$ ), (g)-(i) CCF, (j)-(l) SW net $_{\text {at TOA }}$

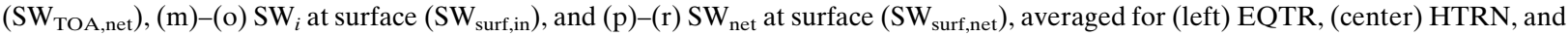
(right) HTRS (see Fig. 1 for identification of the regions). Annual cycles are shown for observations (dashed black lines), model output of PRR (red), and model output of PGR (purple). Vertical bars indicate the interannual variability. The gray shading indicates the uncertainty on the observations, as provided by the authors.

When comparing the reference model to observations, the too negative OLR in PRR indicates that vertical extent of convective clouds is systematically underestimated by COSMO-CLM² , although the annual cycle is modeled with good amplitude and phase (Figs. 5d-f). Also, fractional cloud cover in PRR is slightly underestimated, although mostly situated within the margins of observation uncertainty (Figs. 5g-i).
Net SW radiation is generally underestimated during the monsoon season (months MAM and SON in the equatorial region) and sometimes overestimated during the relatively dry season (Figs. 5p-r). This is caused by a slight deficiency in incoming SW radiation (Figs. 5m-o). A possible reason could be a bias in optical thickness of convective clouds, being respectively too opaque and too transparent. Such a deficiency in optical depth could 

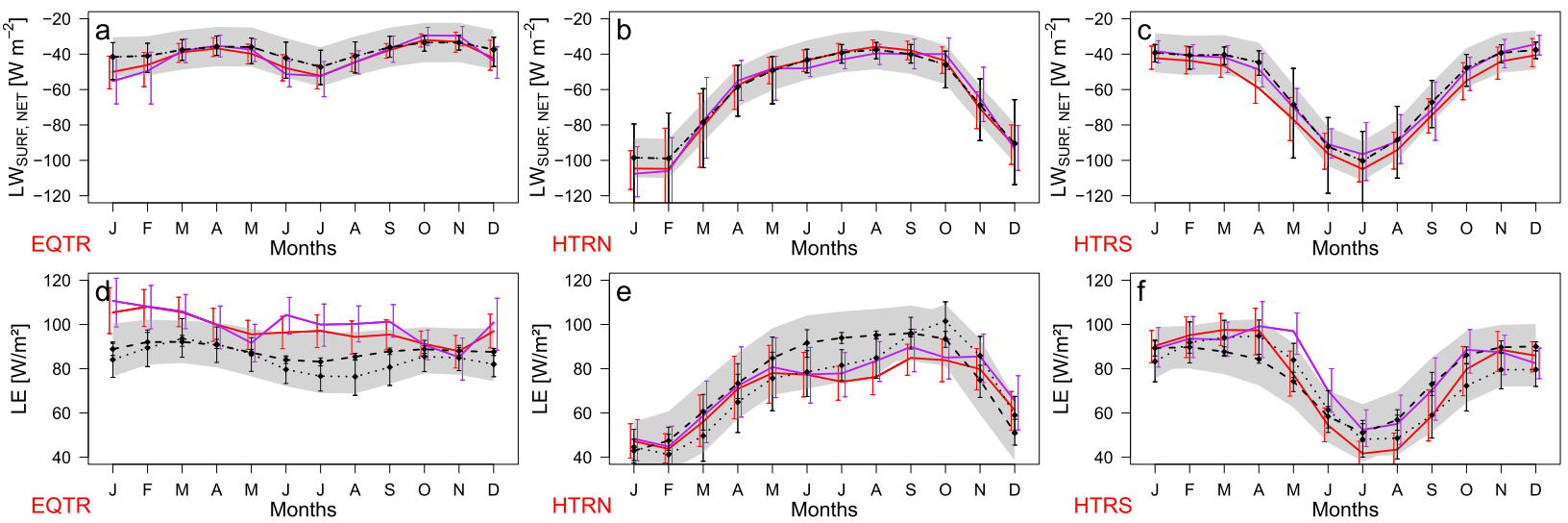

FIG. 6. As in Fig. 5, but for (a)-(c) $\mathrm{LW}_{\text {net }}$ at surface ( $\left.\mathrm{LW}_{\text {surf,net }}\right)$ during 1990-2007 and (d)-(f) LE during 2001-09.

also explain the slight negative bias of net radiation at the TOA during the wet season resulting from too strong reflection by the clouds (Figs. $5 \mathrm{j}-1$ ). In general, these patterns can be found in both PRR and PGR, indicating a deficiency in the regional climate model regardless of the boundary conditions.

Land evapotranspiration or equivalent latent heat flux (Figs. 6d-f) is evaluated using two distinct data products, slightly broadening the combined uncertainty range in which both PRR and PGR simulations are situated. Only for the equatorial region, a systematic overestimation of up to $20 \mathrm{~W} \mathrm{~m}^{-2}$ latent cooling can be noticed, which might explain the slight cold bias in this region (Fig. 3e). The magnitude of the bias shows some seasonal dependency, with the larger overestimation during the dry season (JJA) possibly related to the overestimation of net SW radiation (Fig. 5p) and hence cloud properties.

In general, it can be concluded that COSMO-CLM ${ }^{2}$ is able to represent the present-day climate over tropical Africa well, with the mean annual cycle of most important climatological features mostly within the range of observation uncertainty. Furthermore, when driven by the ECHAM 5 boundary conditions, the model is still able to capture the most important climatological features except for precipitation, which is clearly overestimated during the wet season.

\section{b. Impact of increased $G H G$ concentrations and deforestation}

\section{1) Temperature}

The warming signal resulting from deforestation is generally restricted to the deforested area (Fig. 7a). The average increase in ground surface temperature $\delta T_{g}$ over the entire area where (partial) deforestation is expected to occur, amounts to $0.65^{\circ} \mathrm{C}$, while specifically the districts of Mongala and Equateur are projected to be on average $0.77^{\circ} \mathrm{C}$ warmer (Table 3). The value of $\delta T_{g}$ is higher compared to canopy top warming because of the shading effect (about $+41 \%$ ) and hence, since it better represents the total impact of deforestation on the ground-level ecosystem, it is preferred in the presentation of our results. There is a good correlation between the warming signal and the deforestation pattern (Figs. $7 \mathrm{a}$ and $2 \mathrm{c}$ ), with the majority of affected grid cells increasing by $0.4^{\circ}-1.2^{\circ} \mathrm{C}$, and occasional local hot spots with even higher temperature increases $\left(>1.2^{\circ} \mathrm{C}\right)$.

The isolated GHG forcing (Fig. 7b) causes an increase in $T_{g}$ of about $1.4^{\circ} \mathrm{C}$ in coastal environments and the rain forest lowland, while the inner continental areas experience a warming of about $1.8^{\circ} \mathrm{C}$. This pattern can also be found in ensemble-mean projections of GCMs by Hulme et al. (2001) and Christensen et al. (2007). An even stronger warming is projected for the south of South Sudan $\left(2.4^{\circ}-2.8^{\circ} \mathrm{C}\right)$, which is however not visible in above-mentioned GCM studies and is related to a local small-scale dynamically driven precipitation decrease, with a corresponding change in the energy balance (not shown). Our results indicate that the warming caused by enhanced GHG concentrations is about 2 times larger than the warming caused by deforestation $\left(0.65^{\circ}\right.$ versus $1.47^{\circ} \mathrm{C}$ in all affected grid cells, and $0.77^{\circ}$ versus $1.49^{\circ} \mathrm{C}$ in Mongala and Equateur; see Table 3). Taking into account both forcings, projections for annual average warming between present-day and 2041-60 can locally reach $3^{\circ} \mathrm{C}$ (Fig. $7 \mathrm{c}$ ) with hot spot regions in heavily deforested areas and in southern Sudan.

Some areas such as the coastal region and the eastern forest border are characterized by a lower deforestationinduced surface warming (Fig. 7a), even if they have a high deforestation intensity (Fig. 2c). This indicates that the amount of deforestation is not the only decisive factor to impact $T_{g}$. The differences are correlated with the spatial pattern of deforestation-induced decrease in 


\section{Deforestation and GHG impact: temperature}
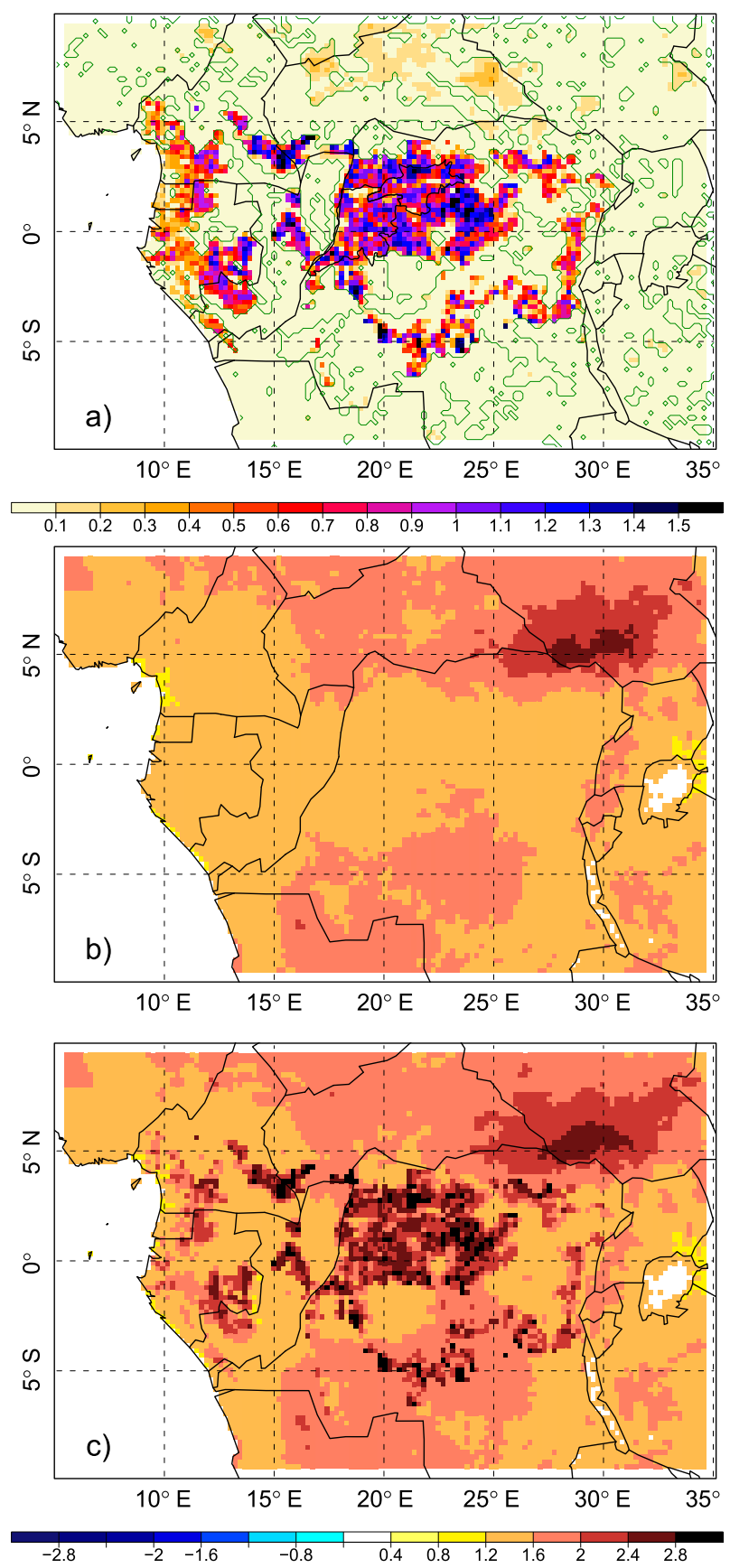

FIG. 7. Difference of 20-yr mean ground surface temperature $\left({ }^{\circ} \mathrm{C}\right)$ (a) between FGD and FGR simulations indicating the impact of deforestation, (b) between FGR and PGR simulations indicating the impact of GHG, and (c) between FGD and PGR simulations indicating the total impact. Significance on the $1 \%$ level is indicated by the green contours. For clarity, color scales are different between (a) and (b),(c). For ease of comparison, the scale used in (a) is the same as the one used in Fig. 8.
TABLE 3. Impact of deforestation and GHG warming on different climatological variables. DEF is the impact of deforestation (FGD minus FGR) and GHG is the impact of increased greenhouse gas concentrations (FGR minus PGR).

\begin{tabular}{|c|c|c|c|c|}
\hline \multirow[b]{2}{*}{ Physical quantity (units) } & \multicolumn{2}{|c|}{ Region A* } & \multicolumn{2}{|c|}{ Region $\mathrm{B}^{* *}$} \\
\hline & DEF & GHG & DEF & GHG \\
\hline Ground & 0.65 & 1.47 & 0.77 & 1.49 \\
\hline Latent heat flux $\left(\mathrm{Wm}^{-2}\right)$ & -5.63 & -0.69 & -7.08 & -0.71 \\
\hline Net $\mathrm{SW}$ radiation, surface $\left(\mathrm{W} \mathrm{m}^{-2}\right)$ & -1.61 & -1.23 & -2.79 & -1.36 \\
\hline Sensible heat flux $\left(\mathrm{W} \mathrm{m}^{-2}\right)$ & 2.80 & 2.50 & 3.22 & 2.56 \\
\hline Net LW radiation, surface $\left(\mathrm{W} \mathrm{m}^{-2}\right)$ & -1.34 & 2.96 & -1.26 & 3.09 \\
\hline Sea level pressure $(\mathrm{Pa})$ & -3.57 & 29.37 & -5.88 & 20.82 \\
\hline Precipitation (\%) & -2.60 & -3.14 & -3.38 & -7.22 \\
\hline
\end{tabular}

* All grid cells affected by the deforestation scenario (with at least $1 \%$ deforestation).

** Grid cells within Mongala and Equateur.

LE (not shown), which is in turn related to the total leaf area index (LAI) within the grid cell (averaged over all vegetation types in the cell): Lawrence et al. (2007) demonstrated that LE is nonlinearly dependent on LAI, with differences in grid cell-averaged LAI between 5 and $4 \mathrm{~m}^{2} \mathrm{~m}^{-2}$ and between 3.5 and $2.5 \mathrm{~m}^{2} \mathrm{~m}^{-2}$ corresponding to evapotranspiration differences of -0.8 and $-0.4 \mathrm{~mm} \mathrm{day}^{-1}$, respectively. The LAI is derived using Moderate Resolution Imaging Spectroradiometer (MODIS) satellite imagery and is part of the default input datasets of the Community Land Model (Lawrence and Chase 2007). It is spatially varying, with lower values near the Atlantic coast and eastern forest borders, regions that are consequently less sensitive to forest removal and thus have a lower temperature increase. The relation between $\delta T_{g}$, deforestation intensity, and LAI (Fig. 8) indicates that a deforestation intensity of $30 \%$ yields an increase in $T_{g}$ of about $0.9^{\circ} \mathrm{C}$ with a LAI of $4-5 \mathrm{~m}^{2} \mathrm{~m}^{-2}$, and about $0.3^{\circ} \mathrm{C}$ with a LAI of $3 \mathrm{~m}^{2} \mathrm{~m}^{-2}$

Temperature increase is larger in the relatively dry seasons [December-February (DJF) and JJA] compared to the wet seasons (MAM and SON), caused by temporal changes in evapotranspiration. Transpiration loss dominates the decrease in latent heat flux and plays a relatively larger role during the dry season, when moisture uptake from the soil reservoir is constrained by root depth, while the abundance of water supply in the wet season partly compensates the decrease (or even absence) of deep rain forest roots. Additionally, the relative soil water stress during the dry season slightly limits the increase in bare soil evaporation. This seasonal behavior is extensively observed (Bonan 2002; Gash and Nobre 1997), simulated (Silva et al. 2006), and well captured by our simulations (not shown). 


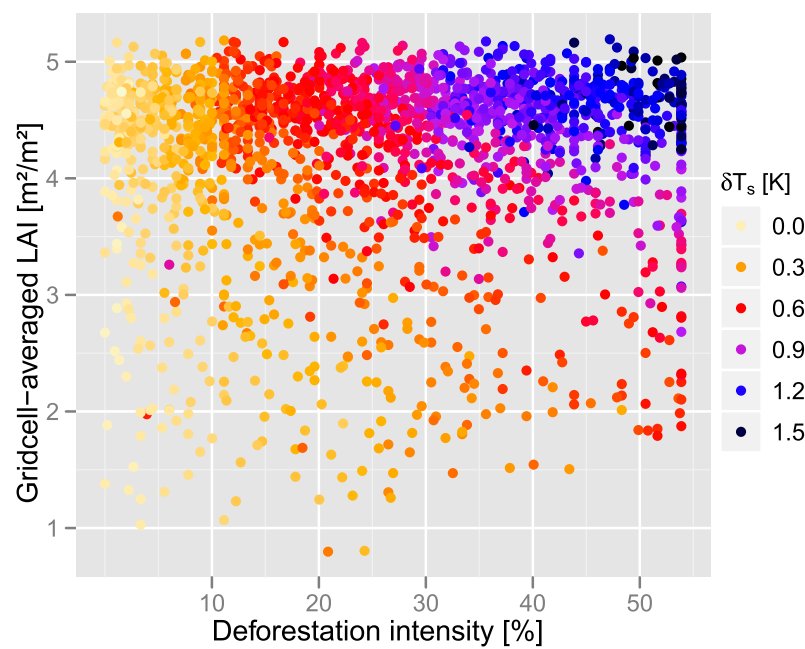

FIG. 8. Dependency of 20-yr mean change in ground surface temperature $\left({ }^{\circ} \mathrm{C}\right)$ on deforestation intensity and LAI for all grid cells affected by the deforestation scenario. For ease of comparison, the color scale is the same as the one used in Fig. 7a.

\section{2) PRecipitation}

As a result of deforestation, modeled precipitation decreases on average by $2.6 \%$ in the deforested grid cells and by $3.4 \%$ in Mongala and Equateur (Table 3). However, the spatial pattern of change in precipitation is different from the change in $T_{g}$ and less correlated with the deforestation intensity. This implies that not only changes in evapotranspiration, but also changes in circulation induced by deforestation play a dominant role in redistributing precipitation, similar to Nogherotto et al. (2013) and Spracklen et al. (2012). In particular over the coastal deforestation hot spots (Republic of the Congo, Gabon, and Cameroon), changes in precipitation extend beyond the deforested areas due to both the monsoon circulation and a deforestation-induced increase in moisture advection from overseas (Figs. 2c and $10 \mathrm{~b})$. In contrast, a consistent local precipitation decrease is projected for the deforestation hotspots in and around Mongala and Equateur, given the limited influence of synoptic-scale circulation compared to the coastal hotspots, and because deforestation induces a heat low in this region (see below), which further inhibits air transport out of the deforested area.

The response of the atmospheric column to deforestation is investigated by means of zonal mean deforestation impact within the cross section region (CRSS; Fig. 1). The atmospheric temperature increase is centered above the region where most deforestation occurs and extends to about 1-km height (Fig. 9a). Average annual temperature increases from around $0.5^{\circ} \mathrm{C}$ (lower atmosphere) to $0.1^{\circ} \mathrm{C}$ (785-m height). A regional heat low develops due to this warming, with negative anomalies of about $-6 \mathrm{~Pa}$ at the surface and about $-1 \mathrm{~Pa}$ aloft (Fig. 9b). The heat low induces near-surface convergence by which the available moisture is dynamically redistributed (Figs. 9c,d): the net result is a regional drying below $700 \mathrm{~m}$ by dry air advection and wetting between 1000 and $2200 \mathrm{~m}$ by moist air advection. The increase in moisture above 1-km height causes a stabilization of the atmospheric column, reflected by an increased equivalent potential temperature $\theta_{e}$ at those levels (Fig. 9e):

$$
\theta_{e}=\left(T+\frac{L_{v}}{C_{p}} q_{v}\right)\left(\frac{p_{0}}{p}\right),
$$

where $L_{v}$ is the latent heat of evaporation $\left(\mathrm{J} \mathrm{kg}^{-1}\right), C_{p}$ is the specific heat capacity of air $\left(1005 \mathrm{~J} \mathrm{~kg}^{-1} \mathrm{~K}^{-1}\right), q_{v}$ is the specific humidity $\left(\mathrm{kg} \mathrm{kg}^{-1}\right), p_{0}$ is the standard reference pressure $(1000 \mathrm{hPa})$, and $p$ is the surface air pressure $(\mathrm{hPa})$. Note that $\theta_{e}$ at lower levels is only slightly modified since the effect of decreased humidity (Fig. 9d) is compensated by the effect of increased temperature (Fig. 9a).

The stabilization of the air results in a decrease in upward convective mass flux (Fig. 10a), less intense convection, and consequently less rainfall (Fig. 10b). In the core area of the heat low, precipitation decreases of $5 \%-10 \%$ are projected.

\section{c. Decomposing deforestation-induced temperature change}

A detailed analysis of the causes for the temperature response to deforestation is performed for a year that was representative for the long-term average. An overview of the net changes in the main components of the energy balance is provided in Figs. 11a and 11c. The decrease in net shortwave radiation $\left(\delta \mathrm{SW}_{\text {net }}\right)$ is mainly caused by the increased albedo of successional vegetation. In the deforested case, evapotranspiration (LE) is lower and net sensible heat flux $(H)$ is higher, indicating a different way of releasing the available energy at the surface.

The net impact of deforestation on surface temperature is decomposed and attributed to direct contributions of modified biophysical processes (such as surface reflection and evapotranspiration) and indirect contributions resulting from atmospheric feedbacks. A common approach for such decomposition is the comparison of multiple model integrations, each having one modified parameter of the successional vegetation. For instance, Davin and de Noblet-Ducoudré (2010) separated the radiative and nonradiative forcing of deforestation on temperature by comparing a model integration in which only the albedo of the forest was changed with a model integration in which all forest parameters were changed. 
Atmospheric cross section of impact

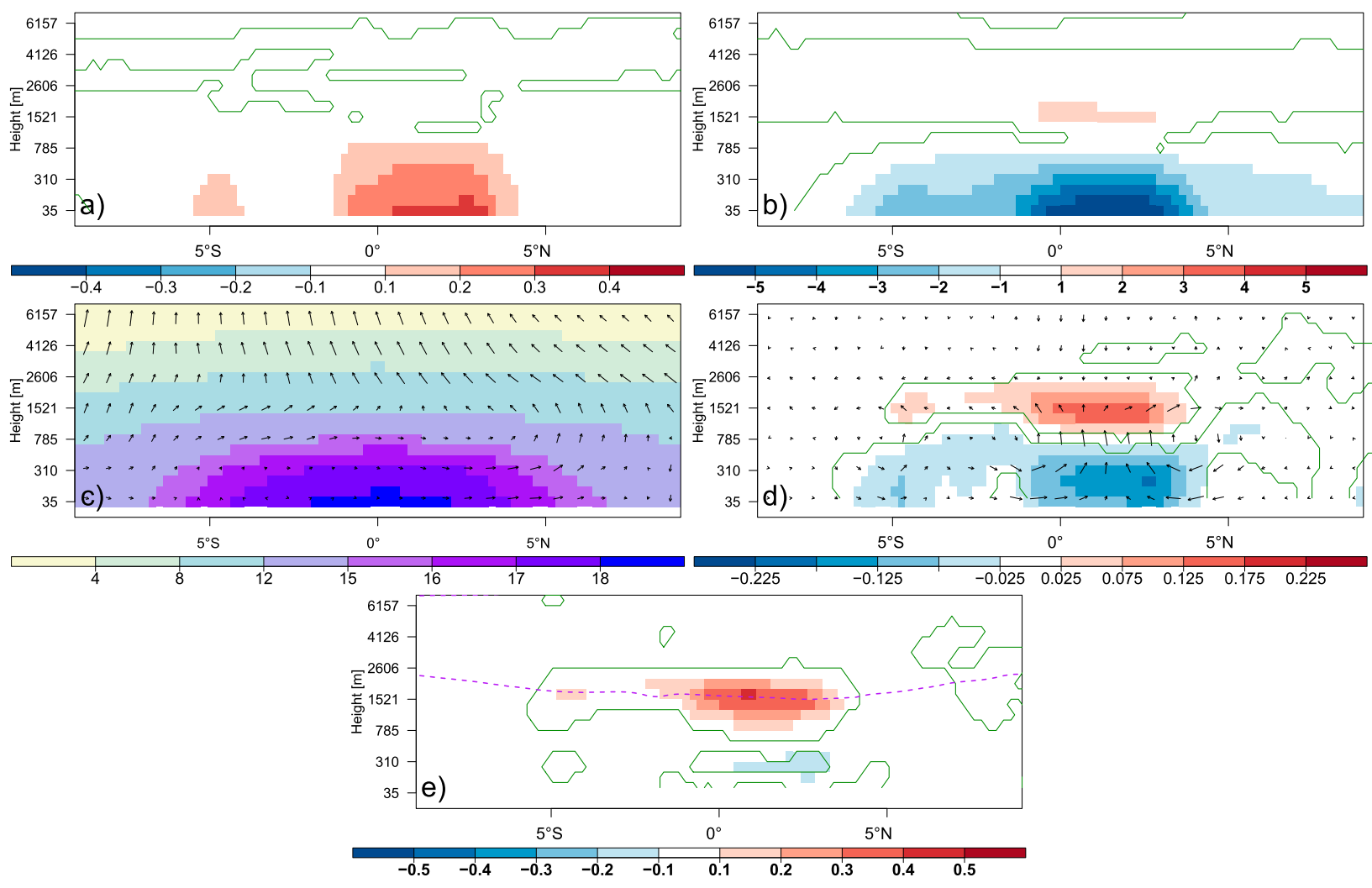

FIG. 9. Zonal mean vertical cross section for the region CRSS (Fig. 1) of the 20-yr (2041-60) mean change resulting from deforestation (FGD minus FGR) for (a) temperature $\left({ }^{\circ} \mathrm{C}\right)$, (b) pressure change $(\mathrm{Pa})$, (d) specific humidity $\left(\mathrm{g} \mathrm{kg}^{-1}\right.$ ) due to heat low-induced net convergence at lower levels, as indicated by arrows, and (e) $\theta_{e}\left({ }^{\circ} \mathrm{C}\right)$ with the dashed purple line indicating the mean convective cloud-base height. Significance at the $1 \%$ level is indicated by the dark green contours. (c) Reference climatology of specific humidity ( $\mathrm{g} \mathrm{kg}^{-1}$ ) in FGR with zonal mean circulation climatology.

The disadvantage of this approach is that a separate model integration is necessary for every parameter for which the forcing is quantified. Furthermore, parameters in complex models are used in different ways; for example, the leaf area index in the Community Land Model is used for the calculation of surface albedo as well as for evapotranspiration (Oleson et al. 2004), complicating the quantification of their individual forcing. Therefore in this study, the surface temperature is decomposed a posteriori in terms associated with the different components of the energy balance, using a method adapted from Jammet et al. (2012), which was in turn adapted and extended from Juang et al. (2007).

The net increase in outgoing energy flux, and hence temperature, can be theorized from Eq. (1) as $4 \epsilon \sigma T_{s}^{3} \delta T_{s}$ : this is the first-order derivative of the left-hand side in Eq. (1), from which $\delta T_{s}$ can be derived by solving the derivative of the equation's right-hand side (Jammet et al. 2012). The surface temperature term $T_{s}$ should be specified to canopy top temperature $T_{c}$, since it is the temperature at which the soil-vegetation complex emits LW radiation to the atmosphere. Note that the impact of deforestation on ground temperature $T_{g}$ is higher, as canopy thickness and hence shading decreases. The breakdown of $\delta H$ into $\delta H_{\text {res }}$ and $\delta H_{\text {tmp }}$ is added in comparison to Jammet et al. (2012):

$$
\begin{aligned}
\delta T_{c}= & \frac{1}{4 \epsilon \sigma T_{c}^{3}}\left[-\mathrm{SW}_{i} \delta \alpha+(1-\alpha) \delta \mathrm{SW}_{i}+\delta \mathrm{LW}_{i}\right. \\
& \left.-\delta \mathrm{LE}+\delta H_{\mathrm{res}}-\delta H_{\mathrm{tmp}}-\delta G-\sigma T_{c}^{4} \delta \epsilon\right]
\end{aligned}
$$

where $\alpha$ is the surface albedo, $\delta H_{\text {res }}$ is the partial change in $H$ due to a modified aerodynamic resistance, and $\delta H_{\mathrm{tmp}}$ is the partial change in $H$ due to a modified temperature gradient. Most terms in Eq. (3) are calculated by subtracting reference from deforested quantities (FGD minus FGR) except the partial changes in sensible heat flux, since $H$ is only provided as a net quantity, as given by Oleson et al. (2004): 


\section{Deforestation impact: precipitation}
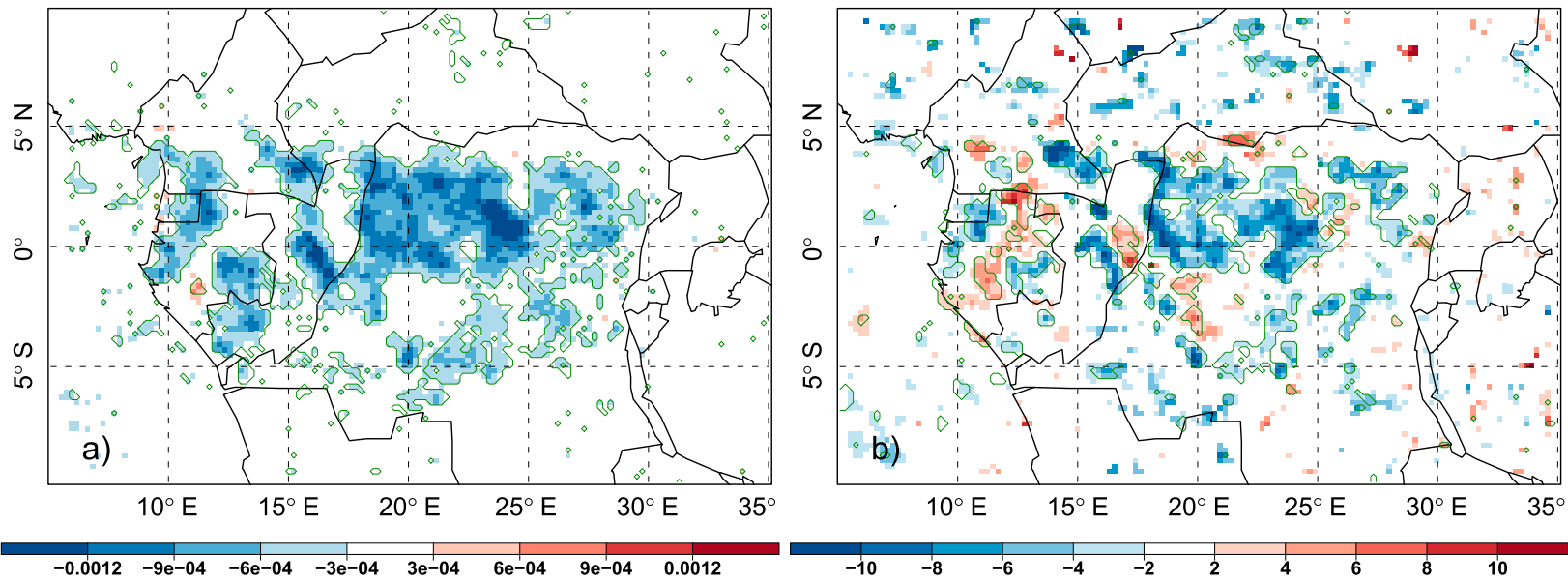

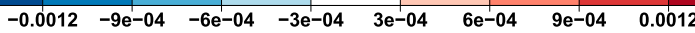

FIG. 10. Plan-view 20-yr (2041-60) mean change resulting from deforestation (FGD minus FGR) for (a) convective mass flux density change at cloud-base height $\left(\mathrm{kg} \mathrm{m}^{-2} \mathrm{~s}^{-1}\right)$ and (b) precipitation change (\%). Significance on the $1 \%$ level is indicated by the green contours.

$$
H=-\rho_{\mathrm{atm}} C_{p} \frac{\left(\theta_{\mathrm{atm}}-T_{c}\right)}{r_{\mathrm{ah}}},
$$

where $\rho_{\text {atm }}$ is the mass density of air and $r_{\mathrm{ah}}$ is the aerodynamic resistance to sensible heat transfer. The value of $\delta H_{\text {res }}$ is then derived by recalculating the hourly model output by which $r_{\text {ah }}$ is taken from the deforested model run (FGD) but the canopy and atmospheric temperature are taken unmodified from the reference run (FGR). The difference between $\delta H$ and $\delta H_{\text {res }}$ is the flux component caused by changes in the vertical temperature gradient $\delta H_{\mathrm{tmp}}$.

The different terms in Eq. (3) represent individual contributing forcings on canopy temperature and are expressed in kelvin. The parameters and flux components responsible for these forcings are shown with their corresponding forcing in Figs. 11b and 11d.

Successional vegetation is brighter and therefore reflects more incoming radiation, resulting in a negative contribution to $\delta T_{c}$ from changing albedo $(\alpha ;$ Figs. $11 \mathrm{~b}, \mathrm{~d})$. Its cooling impact is small $\left(-0.25^{\circ} \mathrm{C}\right)$ and not decisive in defining the sign of the net temperature change. The lower roughness length of successional vegetation increases aerodynamic resistance, slows down heat transfer away from the canopy, and hence corresponds to a positive contribution of about $+1.35^{\circ} \mathrm{C}\left(H_{\text {res }}\right.$; Figs. $\left.11 \mathrm{~b}, \mathrm{~d}\right)$. A decrease in evapotranspiration and hence latent cooling yields a positive contribution to $\delta T_{c}$ of $+1-$ $1.25^{\circ} \mathrm{C}$ (LE; Figs. $\left.11 \mathrm{~b}, \mathrm{~d}\right)$. This is caused by various parameter changes of successional vegetation, being lower roughness length, root depth, leaf and stem area index, and stomatal conductance. The impact of evapotranspiration includes indirect feedbacks since latent heat of vaporization and air saturation are partly dependent on temperature, which makes it impossible to separate between direct (biophysical) and indirect (feedback) components of LE. Its impact on temperature is slightly lower compared to the direct impact of $\delta H_{\text {res }}$, but dominant when compared to the net $\delta H$. The impact resulting from the changing surface emissivity $\epsilon$ is of marginal importance (Figs. 11b,d).

An increased temperature gradient between canopy top and atmosphere is created due to the abovementioned direct biogeophysical forcings. This induces a strong upward sensible heat flux, transporting part of the local heat increase to the atmosphere (therewith acting as a negative feedback) and thus indirectly cooling the canopy by around $-1.85^{\circ} \mathrm{C}\left(H_{\mathrm{tmp}} ;\right.$ Figs. $\left.11 \mathrm{~b}, \mathrm{~d}\right)$. A large difference can be noticed between the two counteracting components of sensible heat (Figs. 11b,d), from which the net effect is a cooling of $-0.5^{\circ} \mathrm{C}$. The contribution of changing incoming solar radiation $\left(\mathrm{SW}_{i}\right.$; Figs. $\left.11 \mathrm{~b}, \mathrm{~d}\right)$ is mostly a result of the indirect feedback of modified cloud cover. This component is only of significance when considering the districts Mongala and Equateur, where increasing cloud cover reduces $\mathrm{SW}_{i}$ and hence acts as a negative feedback $\left(-0.2^{\circ} \mathrm{C}\right)$. Over the entire area affected by deforestation, cloud cover is not significantly altered and hence the impact on $\delta T_{c}$ is negligible. The increase of downward LW radiation emitted by the atmosphere is caused by the atmospheric temperature, which is increased mainly due to the larger sensible heat flux. Additionally, cloud cover plays a role since it furthermore enhances downward LW radiation. Together, $\delta \mathrm{LW}_{i}$ contributes $+0.25^{\circ}-0.4^{\circ} \mathrm{C}$ to the net change in canopy temperature $\left(\mathrm{LW}_{i} ;\right.$ Figs. $\left.11 \mathrm{~b}, \mathrm{~d}\right)$. Finally, the impact of $G$ is not significant (Figs. 11b,d).

All contributions to $\delta T_{c}$ add up to $0.49^{\circ}$ and $0.60^{\circ} \mathrm{C}$, for all areas affected by deforestation and for the districts 

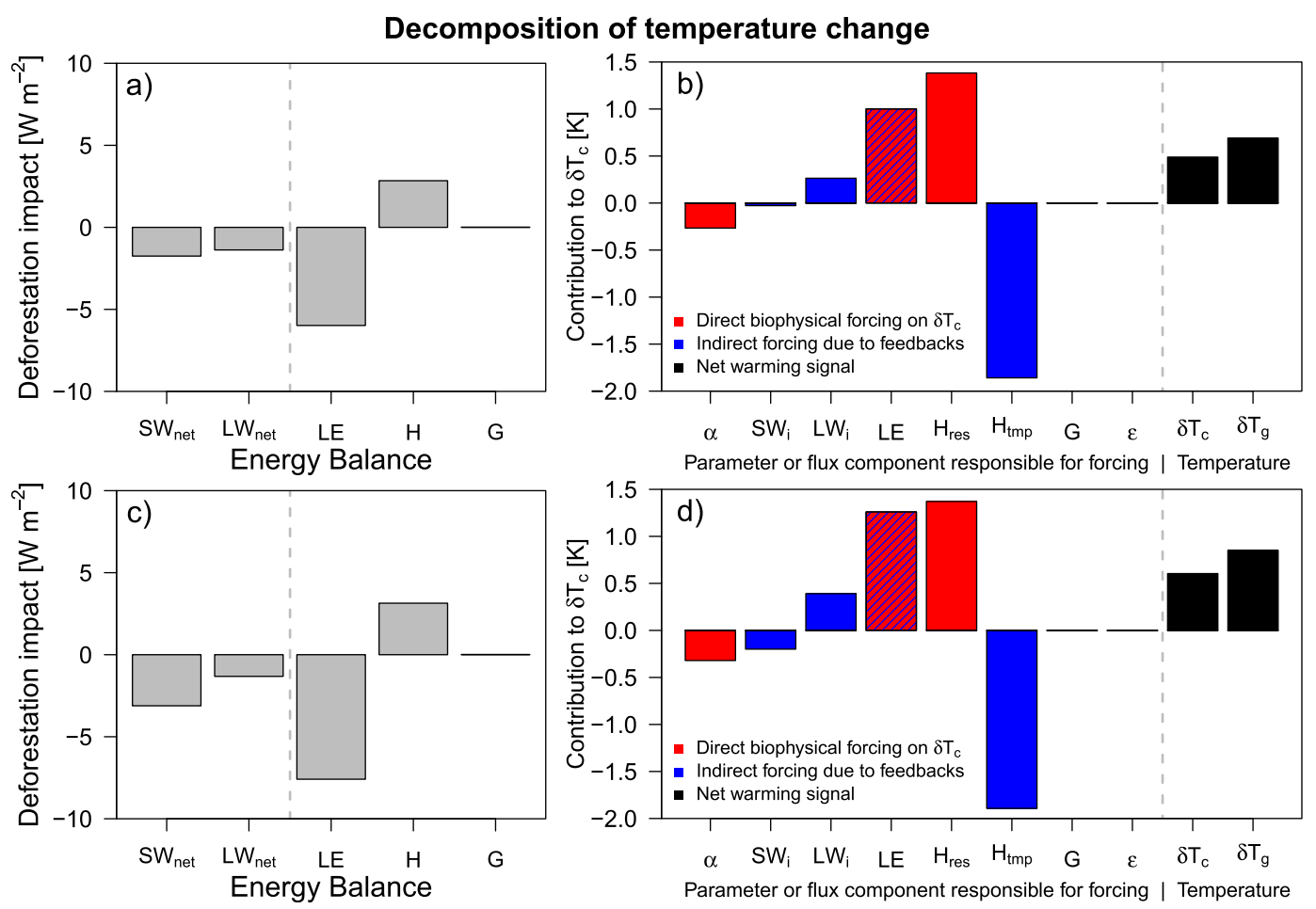

FIG. 11. Deforestation-induced change in surface energy balance components being $\mathrm{SW}_{\text {net }}, \mathrm{LW}_{\text {net }}$, LE, $H$, and $G$ for (a) all grid cells affected by deforestation and (c) for districts Mongala and Equateur. Individual direct and indirect forcings contributing to $\delta T_{c}$ [Eq. (3)] are shown for (b) all grid cells affected by deforestation and (d) for districts Mongala and Equateur. Each forcing is indicated by their corresponding responsible parameter or flux component, with $\alpha$ indicating the forcing caused by a changing albedo, $\mathrm{SW}_{i}$ by changing incoming shortwave radiation, $\mathrm{LW}_{i}$ by changing incoming longwave radiation, $\mathrm{LE}$ by changing evapotranspiration, $H_{\text {res }}$ by changing sensible heat flux due to modified aerodynamic resistance, $H_{\mathrm{tmp}}$ by changing sensible heat flux due to temperature gradient, $G$ by changing ground heat flux, and $\epsilon$ by changing emissivity.

Mongala and Equateur, respectively. Warming of the ground surface $\left(\delta T_{g}\right)$ is higher because of decreased canopy shading $\left(0.69^{\circ}\right.$ and $0.85^{\circ} \mathrm{C}$, respectively). It is typically about $41 \%$ higher compared to $\delta T_{c}$, a proportion that, however, depends on the characteristics of the replacement vegetation (e.g., it would be larger when replacing forest with grass only).

\section{Discussion}

The response of surface climate to deforestation and greenhouse gas emissions has been studied with the intention of enhancing realism compared to preceding impact studies. In the region affected by deforestation, average regional ground surface warming of $+0.7^{\circ} \mathrm{C}$ is projected as a result of forest removal, with local hot spots up to $+1.25^{\circ} \mathrm{C}$. This is lower compared to most of similar preceding studies, for example, $+2.5^{\circ}$ (Polcher and Laval 1994), $+1.8^{\circ}$ (Varejão-Silva et al. 1998), $+5^{\circ}$ (Semazzi and Song 2001), $+1^{\circ}-3^{\circ}$ (Osborne et al. 2004), $+2^{\circ}-3^{\circ}$ (Gibbard et al. 2005), $+1^{\circ}-3^{\circ}$ (Findell et al. 2006), $+1^{\circ}-1.5^{\circ}$ (Paeth et al. 2009), and $+2^{\circ}-4^{\circ} \mathrm{C}$ (Nogherotto et al. 2013). Within this study, the initial rain forest was replaced by realistic successional vegetation, and therefore its corresponding properties are typically in between those from the original rain forest and those from grass or bare soil. Since deforestation scenarios used in preceding impact studies often consist of total forest removal and replacement by grass or bare soil, the modeled impact on surface climate is consequently larger than found in this study. For precipitation, a wide range of projections exists: $+3.4 \%$ (Polcher and Laval 1994), $-10 \%$ (Varejão-Silva et al. 1998), $-10 \%$ (Semazzi and Song 2001), from $-8 \%$ to $-16 \%$ (Osborne et al. 2004), from $-10 \%$ to $-16 \%$ (Paeth et al. 2009), and from $-30 \%$ to $-50 \%$ (Nogherotto et al. 2013); most of them agree on the fact that deforestation forces a regional decrease in precipitation. Again, our study is at the lower part of these estimates, likely a result of the smaller scenario forcing exerted on the reference vegetation. 


\section{a. Implications}

Even though our results indicate somewhat smaller sensitivity than previously thought, the impact on the ecosystem is still expected to be severe. Tropical animal species are more vulnerable to regional ground surface warming compared to the midlatitudes, in particular ectothermal animals such as amphibians, reptiles, insects, and fish (Deutsch et al. 2008): species specialized with respect to temperature (little acclimation capacity), species living in warm habitats (disproportionally suffering from relatively small temperature increases), and species living in nonseasonal climates (no likely changes in behavior and physiology for self-protection) can typically be found in tropical regions (Tewksbury et al. 2008). Local to regional surface warming projected in this study reaches $3^{\circ} \mathrm{C}$, which is enough to cause a significant displacement between the actual and physiologically optimal temperature. For nonectothermal species such as birds, regional warming potentially endangers entire populations in lowland rain forests; poor dispersers (such as the Congo peafowl) are threatened since they are less likely to move to better climatic conditions (Sekercioglu et al. 2012), especially given the large distances to potential refuge regions in the Congo basin lowlands (Wright et al. 2009). Other animals such as mammals (and hence ultimately local human societies) are physiologically less vulnerable to regional surface warming, but suffer indirectly since they are dependent on the directly threatened bottom layers of the food web.

The effect of the regional decrease in precipitation is difficult to quantify; for instance, the balance between this decrease and increased soil exposure determines the sign and magnitude of changing potential erosion rates, which is important in the early growing season. The projections indicate no serious threat for the main subsistence crop used in the Congo basin (cassava), since precipitation decrease is relatively small $(5 \%-10 \%)$ and the crops itself are flexible to these climatic shifts (Ceballos et al. 2011). For other crops (e.g., maize and rice) and plantation yields (e.g., palm nuts), these rainfall changes could be implemented in crop yield models from which the potential threat level can be inferred for each individual species.

\section{b. Applied scenarios}

Several estimates of future deforestation have been published during the past decades, together constituting a range of plausible future forest losses. Most recent examples are the harmonized land use scenarios of Hurtt et al. (2011), consisting of four different trajectories for future land cover on a global grid and used in phase 5 of the Climate Model Intercomparison Project
(CMIP5; see, e.g., Jones et al. 2011; Dufresne et al. 2013). Although being the current state of the art for large-scale global impact studies, the coarse resolution limits their application to GCM studies, and hence they are not suitable for our purposes. Given its spatially explicit character, the use of high-resolution input data, and the inclusion of small-scale processes, we opted for the regional scenario of Justice et al. (2001) adjusted using "business-as-usual" deforestation rates, which typically result in an intermediate projection of forest loss compared to, say, mitigation or expansion scenarios (Wright 2010). Indeed, relative to the four representative concentration pathway (RCP) scenarios discussed in Hurtt et al. (2011), our estimated total amount of forest loss by $2050(-16 \%)$ takes an intermediate position but tending more to the RCP 4.5 and RCP6.0 scenarios, which have moderate emissions (but lower deforestation rates).

Although the deforestation we adopted and the emission scenario A1B are not explicitly related, both scenarios are nonetheless compatible given the shared socioeconomic assumptions of the respective driving algorithms. For instance, both assume (i) a marketoriented regulation of human-environment interactions, (ii) the absence of a coordinated environmental impact mitigation strategy, and (iii) an intermediate position within the spread of projected impact (i.e., both scenarios do not tend toward high or low extreme projections), and, finally, both scenarios assume (iv) roughly similar population sizes for the coming decades, although growth rates diverge after 2040. Although these scenarios are the best currently available, we believe that a future joint effort is required to link global-scale RCP scenarios to high-resolution, spatially explicit regional deforestation scenarios.

\section{Conclusions}

The possible impact of deforestation on the regional climate has been studied during the last two decades using global or regional climate models with a wide range of scenarios, resolutions, deforestation estimates, land surface complexity, and replacement vegetation. Although some of the studies made considerable efforts to enhance the realism of their simulations, none of them combined all the following key elements: a spatially explicit deforestation scenario, a corresponding fine model grid resolution, a plausible estimate of total rain forest removal, a state-of-the-art SVAT scheme, and finally a realistic replacement of rain forest with successional vegetation. This study incorporates all those elements and therefore aims to quantify and understand the future climatological impact of deforestation using realistic simulations. 
An evaluation of the RCM, driven by ERA-Interim, shows an adequate representation of precipitation and temperature: the most important spatial patterns are captured by the model, and the phase and amplitude of the mean annual cycle are similar to observations. However, when driven by the GCM boundary conditions, precipitation is overestimated, which is a result of surface waters that are too warm in ECHAM5. Mean annual cycles of cloud cover, precipitable water, evapotranspiration, and longwave and shortwave components of the energy balance are mostly simulated within the margins of observation uncertainty.

Deforestation results in a modeled ground surface warming of about $0.7^{\circ} \mathrm{C}$, with local hot spots of up to $1.25^{\circ} \mathrm{C}$ warming (in addition to the more uniformly distributed temperature increase due to increased GHG concentrations). The temperature increase is directly related to deforestation intensity and initial leaf area index, and hence has a clear spatial pattern related to those two explaining factors. The impact of deforestation on surface temperature is about half the greenhouse gas-induced surface warming in this region, given the medium SRES A1B scenario forcing and using ECHAM5 boundary conditions. Spatial patterns of change in precipitation are less clear: a large concentration of forest removal and hence regional warming is necessary to develop a significant heat low, which is the case for a large core area in DR Congo. The resulting surface convergence redistributes moisture in the boundary layer, thereby stabilizing the atmosphere and reducing convection intensity and hence decreasing precipitation amounts by about $5 \%-10 \%$ in this region.

Finally, the warming signal at the canopy top is decomposed into individual contributions. Increased albedo has a minor cooling impact $\left(-0.25^{\circ} \mathrm{C}\right)$, which is largely compensated by the decreased evapotranspiration (responsible for $+1^{\circ}-1.25^{\circ} \mathrm{C}$ ). The resulting energy excess is about equally divided between an increased sensible heat flux to the atmosphere and a localized heating resulting in increasing outgoing longwave radiation.

Although this study has been done with greatest care for achieving realism and maximum use of existing knowledge and currently available technology, several possible improvements for further research can be mentioned. Next-generation computer architectures will allow long-term simulations for the same model domain size (encompassing the entire rain forest) with much more detail, allowing for explicit resolving of moist convection instead of its gridscale parameterization that was used in this study (Tiedtke 1989). Similarly, more and finer deforestation scenarios are needed in order to keep pace with the increasing resolution of climate models.
Especially for the central African rain forest such scenarios are needed.

Acknowledgments. The authors sincerely thank the editor and the reviewers for their constructive remarks. For the model simulations we used the infrastructure of the VSC Flemish Supercomputer Center funded by the Hercules Foundation and the EWI Department of the Flemish government. We thank the CLM community for the model code and general assistance in the use of the model. In particular, we are indebted to E. Davin from ETH Zurich for developing and providing the coupled COSMO-CLM ${ }^{2}$ model, and to H.-J. Panitz for the personal and to-the-point advice on the model configuration. Access to ERA-Interim and ECHAM5 was provided by ECMWF and the Max-Plank-Institut für Meteorologie, respectively.

\section{APPENDIX A}

\section{Remapping of the Original Scenario}

The initial forest areas in COSMO-CLM ${ }^{2}$ and Justice et al. (2001) are 1868089 and $1839660 \mathrm{~km}^{2}$, respectively, which are very similar. The COSMO-CLM ${ }^{2}$ model grid has a resolution of $0.22^{\circ}$. However, the scenario of Justice et al. (2001) has a native resolution of $0.10^{\circ}$, from which every deforested grid cell is assigned a value of 1 while the untouched grid cells have a value of 0 (Fig. A1a). The scenario is projected to the $0.22^{\circ}$ grid while conserving the total sum (of deforested surface area). The new grid cells of the remapped scenario will have values ranging between 0 and $1(0 \%-100 \%)$, depending on the proportion of original deforested pixels within each new $0.22^{\circ}$ grid cell (Figs. A1a,b).

\section{APPENDIX B}

\section{Modification of Deforestation Amount}

According to the original scenario of Justice et al. (2001), about $30 \%$ of the forest (or $571975 \mathrm{~km}^{2}$ ) would be removed by 2050 (Fig. A1b; Table 2). This proportion will be referred to as $r$, and is mentioned at the top of Figs. A1a and A1b.

Our study intends to complement existing studies in which all forest is removed by using a plausible estimate of future forest loss. Because of the lack of computational resources to explore the full range of plausible scenarios, and analogous to our choice of the SRES A1B scenario, a single moderate scenario is chosen. Our approach is based on a continuation of existing deforestation trends 
Construction of the deforestation scenario

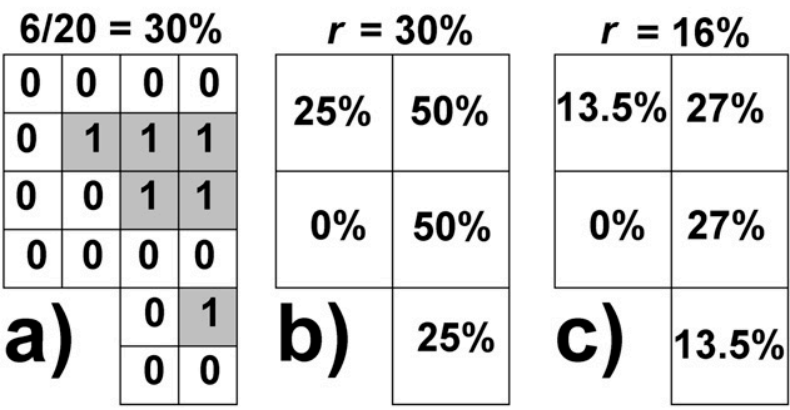

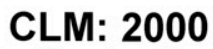

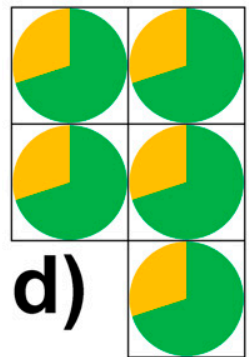

CLM: 2050

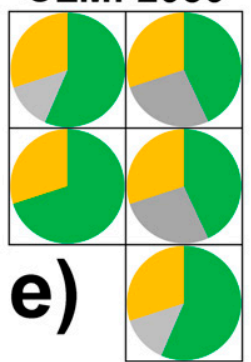

FIG. A1. Conceptual overview of the methodology. (a) Future deforestation scenario as published by Justice et al. (2001) with $0.10^{\circ}$ resolution: " 1 " represents a deforested grid cell. (b) Scenario conservatively remapped to the climate model grid with $0.22^{\circ}$ resolution: the values are area-weighted averages. (c) Remapped scenario adjusted with a scale factor $(0.53)$ in order to obtain more realistic total deforestation proportion $r$ of $16 \%$, instead of $30 \%$. (d) Hypothetical present-day land cover of COSMO-CLM ${ }^{2}$; green is forest and yellow is nonforest. (e) Implementation of the future deforestation scenario in COSMO-CLM ${ }^{2}$; gray is replacement vegetation.

in the future, which typically results in an intermediate projection of forest loss compared to, for instance, mitigation or expansion scenarios (Wright 2010). The business-as-usual model calculates the relative amount of present-day forest that will be removed by 2050 $(r$; Wright 2010). It requires time span $y$ and net annual deforestation rate (NADR):

$$
r=100-100\left[(1-\mathrm{NADR})^{y}\right] .
$$

On average, a present-day NADR of $0.35 \%(0.0035)$ is estimated for the Congo basin (Table 2). When using a time span from 2000 to 2050 (50 yr), Eq. (B1) results in about $16 \%$ of present-day forest to be removed by 2050 , or $308152 \mathrm{~km}^{2}$. This is significantly less than the $31 \%$ from Justice et al. (2001), showing the need for an adjustment. Although useful as a projection of the spatial extent, the original scenario is likely a worst-case scenario. Similarly, because of the binary nature of the scenario, it is assumed that each postclearing deforested pixel of $10 \times 10 \mathrm{~km}^{2}\left(0.10^{\circ}\right)$ is completely forest-free: however, often smaller patches of primary forest remain intact because of local topography or soil conditions.

Therefore, we applied a scale factor to adjust the scenario of Justice et al. (2001) to a more conservative assumption: each "deforested" pixel remains partly forested, in such a way that the proportion of initial forest which is removed by 2050 ( $r=16 \%$; Fig. A1c). The scale factor is simply calculated as the proportion of the calculated $r$ based on literature to the scenario-based $r$, being $16.1 \%$ divided by $30.6 \%$ or 0.53 . The deforested amount in every pixel is then multiplied by this scale factor in order to obtain a total deforestation amount in agreement with currently estimated deforestation rates and a business-as-usual scenario (Fig. A1c). Compared to the global land cover projections of Hurtt et al. (2011) related to four RCPs, our regional scenario takes an intermediate position between the low and high extremes (not shown).

The reprojected and adjusted scenario (Fig. 2c) is then imposed on the initial (present-day) land cover map of COSMO-CLM ${ }^{2}$ by subtracting it from the existing primary forest amounts (Figs. A1d,e). The resulting map of primary forest in COSMO-CLM ${ }^{2}$ is shown in Fig. $2 b$.

\section{APPENDIX C}

\section{Creation of New Vegetation Types}

Information about successional vegetation is taken from Akkermans et al. (2013), reporting the following areal proportions of successional vegetation observed after deforestation in the Congo basin: $5 \%$ bare soil, $22 \%$ crops, $9 \%$ grass, $33 \%$ forest regrowth, and $30 \%$ young secondary forest. Forest regrowth and secondary forest are not by default included in COSMO-CLM ${ }^{2}$; hence, their parameters were added to the original model.

The structural phenology of young secondary forest (e.g., root distribution, roughness length, leaf/stem orientation, and stem area index) is significantly different from the evergreen primary forest and more similar to the deciduous woodlands typically bordering the equatorial rain forest. Hence these parameters are taken from the existing vegetation type broadleaf deciduous tropical forest. On the other hand, the evergreen characteristics (e.g., canopy seasonality, leaf longevity, and fire resistance) and physiology (e.g., soil water potential and nitrogen limitation) are more directly related to the existing rain forest vegetation type. Based on observations, the absolute LAI is calculated as $51 \%$ of the rain forest LAI (Akkermans et al. 2013). 
Forest regrowth is an intermediate vegetation stage with mixed characteristics of the preceding and following fallow stages (grass and young secondary forest). Therefore, its areal proportion is equally split and allocated to those two vegetation types (Akkermans et al. 2013).

\section{REFERENCES}

Achard, F., H. Eva, H. Stibig, P. Mayaux, J. Gallego, T. Richards, and J. Malingreau, 2002: Determination of deforestation rates of the world's humid tropical forests. Science, 297, 999-1002, doi:10.1126/science.1070656.

Akkermans, T., and Coauthors, 2012: Validation and comparison of two soil-vegetation-atmosphere transfer models for tropical Africa. J. Geophys. Res., 117, G02013, doi:10.1029/ 2011JG001802.

, P. Moonen, B. Verbist, A. Van Rompaey, and N. Van Lipzig, 2013: Quantifying successional land cover after clearing of tropical rainforest along forest frontiers in the Congo Basin. Phys. Geogr., 34, 417-440, doi:10.1080/02723646.2013.855698.

Bloom, S., and Coauthors, 2005: Documentation and validation of the Goddard Earth Observing System (GEOS) data assimilation system, version 4. NASA/TM-2005-104606, Vol. 26, 165 pp. [Available online at http://ntrs.nasa.gov/search.jsp? $\mathrm{R}=20050175690$.]

Bonan, G. B., 2002: Ecological Climatology: Concepts and Applications. Cambridge University Press, 678 pp.

2008: Forests and climate change: Forcings, feedbacks, and the climate benefits of forests. Science, 320, 1444-1449, doi:10.1126/science.1155121.

Ceballos, H., J. Ramirez, A. C. Bellotti, A. Jarvis, and E. Alvarez, 2011: Adaptation of cassava to changing climates. Crop Adaptation to Climate Change, S. S. Yadav et al., Eds., Wiley, 411-425.

Chen, T.-C., J.-H. Yoon, K. J. St Croix, and E. S. Takle, 2001: Suppressing impacts of the Amazonian deforestation by the global circulation change. Bull. Amer. Meteor. Soc., 82, 2209-2216, doi:10.1175/1520-0477(2001)082<2209:SIOTAD>2.3.CO;2.

Christensen, J. H., and Coauthors, 2007: Regional climate projections. Climate Change, 2007: The Physical Science Basis. S. Solomon et al., Eds., Cambridge University Press, 847-940.

Chu, P.-S., Z.-P. Yu, and S. Hastenrath, 1994: Detecting climate change concurrent with deforestation in the Amazon basin: Which way has it gone? Bull. Amer. Meteor. Soc., 75, 579-583, doi:10.1175/1520-0477(1994)075<0579:DCCCWD>2.0.CO;2.

Claussen, M., V. Brovkin, and A. Ganopolski, 2001: Biogeophysical versus biogeochemical feedbacks of large-scale land cover change. Geophys. Res. Lett., 28 (6), 1011-1014, doi:10.1029/2000GL012471.

Davin, E. L., and N. de Noblet-Ducoudré, 2010: Climatic impact of global-scale deforestation: Radiative versus nonradiative processes. J. Climate, 23, 97-112, doi:10.1175/2009JCLI3102.1.

_ R. Stöckli, E. Jaeger, S. Levis, and S. Seneviratne, 2011: COSMO-CLM ${ }^{2}$ : A new version of the COSMO-CLM model coupled to the Community Land Model. Climate Dyn., 37, 1889-1907, doi:10.1007/s00382-011-1019-z.

Dee, D., and Coauthors, 2011: The ERA-Interim reanalysis: Configuration and performance of the data assimilation system. Quart. J. Roy. Meteor. Soc., 137, 553-597, doi:10.1002/qj.828.

Deutsch, C. A., J. J. Tewksbury, R. B. Huey, K. S. Sheldon, C. K. Ghalambor, D. C. Haak, and P. R. Martin, 2008: Impacts of climate warming on terrestrial ectotherms across latitude. Proc. Natl. Acad. Sci. USA, 105, 6668-6672, doi:10.1073/ pnas.0709472105.
Dirmeyer, P. A., and J. Shukla, 1994: Albedo as a modulator of climate response to tropical deforestation. J. Geophys. Res., 99 (D10), 20 863-20 877, doi:10.1029/94JD01311.

Dufresne, J.-L., and Coauthors, 2013: Climate change projections using the IPSL-CM5 Earth System Model: From CMIP3 to CMIP5. Climate Dyn., 40, 2123-2165.

Durieux, L., L. A. T. Machado, and H. Laurent, 2003: The impact of deforestation on cloud cover over the Amazon arc of deforestation. Remote Sens. Environ., 86, 132-140, doi:10.1016/ S0034-4257(03)00095-6.

Ernst, C., and Coauthors, 2010: Congo Basin forest cover change estimate for 1990, 2000 and 2005 by Landsat interpretation using an automated object-based processing chain. The International Archives of the Photogrammetry, Remote Sensing and Spatial Information Sciences, XXXVIII-4/C7, 1-6. [Available online at http://www.isprs.org/proceedings/xxxviii/4-C7/ pdf/ErnstC_126.pdf.]

FAO, 2000: Global Forest Resources Assessment 2000: Main Report. U.N. Food and Agricultural Organization, 479 pp. [Available online at http://www.fao.org/forestry/fra/2000/report/en/.]

Findell, K. L., T. R. Knutson, and P. Milly, 2006: Weak simulated extratropical responses to complete tropical deforestation. J. Climate, 19, 2835-2850, doi:10.1175/JCLI3737.1.

Fleming, T. H., 1986: Secular changes in Costa Rican rainfall: Correlation with elevation. J. Trop. Ecol., 2, 87-91, doi:10.1017/ S0266467400000638.

Gash, J., and C. Nobre, 1997: Climatic effects of Amazonian deforestation: Some results from ABRACOS. Bull. Amer. Meteor. Soc., 78, 823-830, doi:10.1175/1520-0477(1997)078<0823: CEOADS $>2.0 . \mathrm{CO} ; 2$.

Gibbard, S., K. Caldeira, G. Bala, T. J. Phillips, and M. Wickett, 2005: Climate effects of global land cover change. Geophys. Res. Lett., 32, L23705, doi:10.1029/2005GL024550.

Grasselt, R., D. Schuttemeyer, K. Warrach-Sagi, F. Ament, and C. Simmer, 2008: Validation of TERRA-ML with discharge measurements. Meteor. Z., 17 (6), 763-773, doi:10.1127/ 0941-2948/2008/0334.

Harris, I., P. Jones, T. Osborn, and D. Lister, 2013: Updated highresolution grids of monthly climatic observations-The CRU TS3.10 dataset. Int. J. Climatol., doi:10.1002/joc.3711.

Henderson-Sellers, A., and V. Gornitz, 1984: Possible climatic impacts of land cover transformations, with particular emphasis on tropical deforestation. Climatic Change, 6, 231-257, doi:10.1007/BF00142475.

Huffman, G., and Coauthors, 2007: The TRMM Multisatellite Precipitation Analysis (TMPA): Quasi-global, multiyear, combined-sensor precipitation estimates at fine scales. J. Hydrometeor., 8, 38-55, doi:10.1175/JHM560.1.

Hulme, M., R. Doherty, T. Ngara, M. New, and D. Lister, 2001: African climate change: 1900-2100. Climate Res., 17, 145-168, doi:10.3354/cr017145.

Hurtt, G., and Coauthors, 2011: Harmonization of land-use scenarios for the period 1500-2100: 600 years of global gridded annual land-use transitions, wood harvest, and resulting secondary lands. Climatic Change, 109, 117-161, doi:10.1007/ s10584-011-0153-2.

Jaeger, E., I. Anders, D. Luthi, B. Rockel, C. Schar, and S. Seneviratne, 2008: Analysis of ERA40-driven CLM simulations for Europe. Meteor. Z., 17, 349-367, doi:10.1127/0941-2948/2008/0301.

Jammet, M., B. Gielen, E. Moors, S. Rambal, D. Loustau, P. Stoy, and S. Luyssaert, 2012: Biophysical effects of forest management on surface temperature. Geophysical Research Abstracts, Vol. 14, Abstract EGU2012-4485-1. [Available 
online at http://meetingorganizer.copernicus.org/EGU2012/ EGU2012-4485-1.pdf.]

Jones, C., and Coauthors, 2011: The HadGEM2-ES implementation of CMIP5 centennial simulations. Geosci. Model Dev., 4, 543-570, doi:10.5194/gmd-4-543-2011.

Juang, J.-Y., G. Katul, M. Siqueira, P. Stoy, and K. Novick, 2007: Separating the effects of albedo from eco-physiological changes on surface temperature along a successional chronosequence in the southeastern United States. Geophys. Res. Lett., 34, L21408, doi:10.1029/2007GL031296.

Jung, M., and Coauthors, 2011: Global patterns of land-atmosphere fluxes of carbon dioxide, latent heat, and sensible heat derived from eddy covariance, satellite, and meteorological observations. J. Geophys. Res., 116, G00J07, doi:10.1029/2010JG001566.

Jungclaus, J., and Coauthors, 2006: Ocean circulation and tropical variability in the coupled model ECHAM5/MPI-OM. J. Climate, 19, 3952-3972, doi:10.1175/JCLI3827.1.

Justice, C., D. Wilkie, Q. Zhang, J. Brunner, and C. Donoghue, 2001: Central African forests, carbon and climate change. Climate Res., 17, 229-246, doi:10.3354/cr017229.

Kothe, S., D. Lüthi, and B. Ahrens, 2014: Analysis of the West African monsoon system in the regional climate model COSMOCLM. Int. J. Climatol., 34, 481-493, doi:10.1002/joc.3702.

Lawrence, D. M., P. E. Thornton, K. W. Oleson, and G. B. Bonan, 2007: The partitioning of evapotranspiration into transpiration, soil evaporation, and canopy evaporation in a GCM: Impacts on land-atmosphere interaction. J. Hydrometeor., $\mathbf{8}$, 862-880, doi:10.1175/JHM596.1.

Lawrence, P. J., and T. N. Chase, 2007: Representing a new MODIS consistent land surface in the Community Land Model (CLM 3.0). J. Geophys. Res., 112, G01023, doi:10.1029/2006JG000168.

Lean, J., and D. Warrilow, 1989: Simulation of the regional climatic impact of Amazon deforestation. Nature, 342, 411-413, doi:10.1038/342411a0.

Mayaux, P., and J. P. Malingreau, 2001: Le couvert forestier d'Afrique centrale: Un nouvel état des lieux. Bull. Sci. Acad. Roy. Sci. Outre-Mer, 46, 475-486.

Maynard, K., and J.-F. Royer, 2004: Effects of "realistic" landcover change on a greenhouse-warmed African climate. Climate Dyn., 22, 343-358, doi:10.1007/s00382-003-0371-z.

McGuffie, K., A. Henderson-Sellers, H. Zhang, T. Durbidge, and A. Pitman, 1995: Global climate sensitivity to tropical deforestation. Global Planet. Change, 10, 97-128, doi:10.1016/ 0921-8181(94)00022-6.

Meher-Homji, V., 1991: Probable impact of deforestation on hydrological processes. Climatic Change, 19, 163-173, doi:10.1007/ BF00142223.

Miralles, D., T. Holmes, R. De Jeu, J. Gash, A. Meesters, and A. Dolman, 2011: Global land-surface evaporation estimated from satellite-based observations. Hydrol. Earth Syst. Sci., 15, 453-469, doi:10.5194/hess-15-453-2011.

Müller, C., 2009: Climate change impact on Sub-Saharan Africa: An overview and analysis of scenarios and models. Deutsches Institut für Entwicklungspolitik, $58 \mathrm{pp}$. [Available online at http://www.isn.ethz.ch/Digital-Library/Publications/Detail/ ?ots591 =0c54e3b3-1e9c-be1e-2c24-a6a8c7060233\&lng=en\&id $=$ 101270.]

Nakicenovic, N., and Coauthors, 2000: Special report on emissions scenarios. Intergovernmental Panel on Climate Change Tech. Rep., 570 pp.

Nogherotto, R., E. Coppola, F. Giorgi, and L. Mariotti, 2013: Impact of Congo Basin deforestation on the African monsoon. Atmos. Sci. Lett., 14, 45-51, doi:10.1002/asl2.416.
Norris, K., A. Asase, B. Collen, J. Gockowksi, J. Mason, B. Phalan, and A. Wade, 2010: Biodiversity in a forest-agriculture mosaicThe changing face of West African rainforests. Biol. Conserv., 143, 2341-2350, doi:10.1016/j.biocon.2009.12.032.

O'Brien, K. L., 2000: Upscaling tropical deforestation: Implications for climate change. Climatic Change, 44, 311-329, doi:10.1023/ A: 1005531521525

Oleson, K., and Coauthors, 2004: Technical description of the Community Land Model (CLM). NCAR Tech. Note NCAR/ TN-461+STR, 173 pp, doi:10.5065/D6N877R0. , and Coauthors, 2008: Improvements to the Community Land Model and their impact on the hydrological cycle. J. Geophys. Res., 113, G01021, doi:10.1029/2007JG000563.

Osborne, T., D. Lawrence, J. Slingo, A. Challinor, and T. Wheeler, 2004: Influence of vegetation on the local climate and hydrology in the tropics: Sensitivity to soil parameters. Climate Dyn., 23, 45-61, doi:10.1007/s00382-004-0421-1.

Paeth, H., 2004: Regionale Klimamodellierung zur Evaluation der Hauptfaktoren einer voraussichtlichen Klimaänderung in Afrika (Key factors in African climate change evaluated by a regional climate model). Erdkunde, 58, 290-315, doi:10.3112/ erdkunde.2004.04.02

and H.-P. Thamm, 2007: Regional modelling of future African climate north of $15^{\circ} \mathrm{S}$ including greenhouse warming and land degradation. Climatic Change, 83, 401-427, doi:10.1007/ s10584-006-9235-y.

- K. Born, R. Girmes, R. Podzun, and D. Jacob, 2009: Regional climate change in tropical and northern Africa due to greenhouse forcing and land use changes. J. Climate, 22, 114-132, doi:10.1175/2008JCLI2390.1.

, and Coauthors, 2011: Progress in regional downscaling of West African precipitation. Atmos. Sci. Lett., 12, 75-82, doi:10.1002/asl.306.

Panitz, H.-J., P. Berg, G. Schädler, and G. Fosser, 2012: Modelling near future regional climate change for Germany and Africa. High Performance Computing in Science and Engineering '11, W. Nagel, D. Kröner, and M. Resch, Eds., Springer, 503-512.

Pielke, R., J. Adegoke, A. Beltran-Przekurat, C. Hiemstra, J. Lin, U. Nair, D. Niyogi, and T. Nobis, 2007: An overview of regional land-use and land-cover impacts on rainfall. Tellus, 59B, 587-601, doi:10.1111/j.1600-0889.2007.00251.x.

Polcher, J., 1995: Sensitivity of tropical convection to land surface processes. J. Atmos. Sci., 52, 3143-3161, doi:10.1175/ 1520-0469(1995)052<3143:SOTCTL >2.0.CO;2.

, and K. Laval, 1994: The impact of African and Amazonian deforestation on tropical climate. J. Hydrol., 155, 389-405, doi:10.1016/0022-1694(94)90179-1.

Potapov, P. V., S. A. Turubanova, M. C. Hansen, B. Adusei, M. Broich, A. Altstatt, L. Mane, and C. O. Justice, 2012: Quantifying forest cover loss in Democratic Republic of the Congo, 2000-2010, with Landsat ETM + data. Remote Sens. Environ., 122, 106-116, doi:10.1016/j.rse.2011.08.027.

Randall, D. A., and Coauthors, 2007: Climate models and their evaluation. Climate Change 2007: The Physical Science Basis, S. Solomon et al., Eds., Cambridge University Press, 589-662.

Rockel, B., A. Will, and A. Hense, 2008: The regional climate model COSMO-CLM (CCLM). Meteor. Z., 17, 347-348, doi:10.1127/0941-2948/2008/0309.

Roeckner, E., and Coauthors, 2003: The atmospheric general circulation model ECHAM5: Part 1: Model description. MaxPlanck-Institut für Meteorologie Rep. 349, 127 pp.

M. Lautenschlager, and H. Schneider, 2006a: IPCC-AR4 MPI-ECHAM5 T63L31 MPI-OM GR1. 5L40 20C3M run no. 1: 
Atmosphere 6 HOUR values MPImet/MAD Germany. Max-Planck-Institut für Meteorologie, doi:10.1594/WDCC/ EH5-T63L31_OM-GR1.5L40_20C_1_6H.

, - - and - 2006b: IPCC-AR4 MPI-ECHAM5 T63L31 MPI-OM GR1. 5L40 SRESA1B run no. 1: Atmosphere 6 HOUR values MPImet/MAD Germany. Max-Planck-Institut für Meteorologie, doi:10.1594/ WDCC/EH5-T63L31_OM-GR1.5L40_A1B_1_6H.

Rossow, W. B., and R. A. Schiffer, 1999: Advances in understanding clouds from ISCCP. Bull. Amer. Meteor. Soc., 80, 2261-2287, doi:10.1175/1520-0477(1999)080<2261:AIUCFI > 2.0.CO;2.

Rudolf, B., A. Becker, U. Schneider, A. Meyer-Christoffer, and M. Ziese, 2011: New GPCC full data reanalysis version 5 provides high-quality gridded monthly precipitation data. GEWEX News, No. 21, International GEWEX Project Office, Silver Spring, MD, 4-5.

Russell, D., P. Mbile, and N. Tchamou, 2011: Farm and forest in Central Africa: Toward an integrated rural development strategy. J. Sustain. For., 30, 111-132, doi:10.1080/ 10549811003757751.

Salih, A. A., H. Körnich, and M. Tjernström, 2013: Climate impact of deforestation over South Sudan in a regional climate model. Int. J. Climatol., 33, 2362-2375.

Sekercioglu, C., R. Primack, and J. Wormworth, 2012: The effects of climate change on tropical birds. Biol. Conserv., 148, 1-18, doi:10.1016/j.biocon.2011.10.019.

Semazzi, F., and Y. Song, 2001: A GCM study of climate change induced by deforestation in Africa. Climate Res., 17, 169-182, doi:10.3354/cr017169.

Shukla, J., C. Nobre, and P. Sellers, 1990: Amazon deforestation and climate change. Science, 247, 1322-1325, doi:10.1126/ science.247.4948.1322.

Silva, M., S. Franchito, and V. B. Rao, 2006: Effects of Amazonian deforestation on climate: A numerical experiment with a coupled biosphere-atmosphere model with soil hydrology. Theor. Appl. Climatol., 85, 1-18, doi:10.1007/s00704-005-0177-5.

Snyder, P., C. Delire, and J. Foley, 2004: Evaluating the influence of different vegetation biomes on the global climate. Climate Dyn., 23, 279-302, doi:10.1007/s00382-004-0430-0.

Spracklen, D., S. Arnold, and C. Taylor, 2012: Observations of increased tropical rainfall preceded by air passage over forests. Nature, 489, 282-285, doi:10.1038/nature11390.

Stackhouse, P., S. Gupta, S. Cox, T. Zhang, J. Mikovitz, and L. Hinkelman, 2011: 24.5-year SRB data set released. GEWEX News, No. 21, International GEWEX Project Office, Silver Spring, MD, 10-12.

Stöckli, R., and Coauthors, 2008: Use of FLUXNET in the Community Land Model development. J. Geophys. Res., 113, G01025, doi:10.1029/2007JG000562.

Strengers, B., R. Leemans, B. Eickhout, B. de Vries, and L. Bouwman, 2004: The land-use projections and resulting emissions in the IPCC SRES scenarios as simulated by the IMAGE 2.2 model. GeoJournal, 61, 381-393, doi:10.1007/ s10708-004-5054-8.

Sud, Y., W. K. Lau, G. Walker, J. Kim, G. Liston, and P. Sellers, 1996: Biogeophysical consequences of a tropical deforestation scenario: A GCM simulation study. J. Climate, 9, 3225-3247, doi:10.1175/1520-0442(1996)009<3225:BCOATD>2.0.CO;2.

Tanaka, H., N. Ishizaki, and D. Nohara, 2005: Intercomparison of the intensities and trends of Hadley, Walker and monsoon circulations in the global warming projections. SOLA, 1, 7780, doi:10.2151/sola.2005-021.
Tanré, D., J. Geleyn, and J. Slingo, 1984: First results of the introduction of an advanced aerosol-radiation interaction in the ECMWF low resolution global model. Aerosols and Their Climatic Effects, A. Deepak, Ed., A. Deepak Publishing, 133177.

Tewksbury, J. J., R. B. Huey, and C. A. Deutsch, 2008: Putting the heat on tropical animals. Science, 320, 1296-1297, doi:10.1126/ science. 1159328 .

Thiery, W., and Coauthors, 2014a: LakeMIP Kivu: Evaluating the representation of a large, deep tropical lake by a set of onedimensional lake models. Tellus, 66A, 21390, doi:10.3402/ tellusa.v66.21390.

—_, A. Martynov, F. Darchambeau, J.-P. Descy, P.-D. Plisnier, L. Sushama, and N. P. M. van Lipzig, 2014b: Understanding the performance of the FLake model over two African Great Lakes. Geosci. Model Dev., 7, 317-337, doi:10.5194/ gmd-7-317-2014.

Tiedtke, M., 1989: A comprehensive mass flux scheme for cumulus parameterization in large-scale models. Mon. Wea. Rev., 117, 1779-1800, doi:10.1175/1520-0493(1989)117<1779: ACMFSF $>2.0 . \mathrm{CO} ; 2$.

Van Ulden, A., and G. Van Oldenborgh, 2006: Large-scale atmospheric circulation biases and changes in global climate model simulations and their importance for climate change in Central Europe. Atmos. Chem. Phys., 6, 863-881, doi:10.5194/ acp-6-863-2006.

Varejão-Silva, M. A., S. H. Franchito, and V. B. Rao, 1998: A coupled biosphere-atmosphere climate model suitable for studies of climatic change due to land surface alterations. J. Climate, 11, 1749-1767, doi:10.1175/1520-0442(1998)011<1749: ACBACM>2.0.CO;2.

Voldoire, A., and J. Royer, 2004: Tropical deforestation and climate variability. Climate Dyn., 22, 857-874, doi:10.1007/ s00382-004-0423-z.

Warren, W., 1974: A study of climate and forests in the Ranchi Plateau, Part II. Indian For., 100 (5), 291-314.

Wilkie, D., E. Shaw, F. Rotberg, G. Morelli, and P. Auzel, 2000: Roads, development, and conservation in the Congo basin. Conserv. Biol., 14 (6), 1614-1622, doi:10.1046/j.1523-1739.2000.99102.x.

Wright, S. J., 2010: The future of tropical forests. Ann. N. Y. Acad. Sci., 1195, 1-27, doi:10.1111/j.1749-6632.2010.05455.x.

- H. C. Muller-Landau, and J. Schipper, 2009: The future of tropical species on a warmer planet. Conserv. Biol., 23 (6), 1418-1426, doi:10.1111/j.1523-1739.2009.01337.x.

Zeng, N., and J. D. Neelin, 1999: A land-atmosphere interaction theory for the tropical deforestation problem. J. Climate, 12, 857-872, doi:10.1175/1520-0442(1999)012<0857: ALAITF $>2.0 . \mathrm{CO} ; 2$.

Zhang, H., A. Henderson-Sellers, and K. McGuffie, 1996: Impacts of tropical deforestation. Part I: Process analysis of local climatic change. J. Climate, 9, 1497-1517, doi:10.1175/ 1520-0442(1996)009<1497:IOTDPI > 2.0.CO;2.

,-- , and,- 2001 : The compounding effects of tropical deforestation and greenhouse warming on climate. Climatic Change, 49, 309-338, doi:10.1023/A:1010662425950.

Zhang, Q., D. Devers, A. Desch, C. Justice, and J. Townshend, 2005: Mapping tropical deforestation in central Africa. Environ Monit. Assess., 101, 69-83, doi:10.1007/s10661-005-9132-2.

— C. O. Justice, M. Jiang, J. Brunner, and D. S. Wilkie, 2006: A GIS-based assessment on the vulnerability and future extent of the tropical forests of the Congo basin. Environ. Monit. Assess., 114, 107-121, doi:10.1007/s10661-006-2015-3. 